\title{
Shotgun proteomics reveals physiological response to ocean acidification in Crassostrea gigas
}

\author{
Emma Timmins-Schiffman', William D Coffey ${ }^{2}$, Wilber Hua², Brook L Nunn ${ }^{3}$, Gary H Dickinson ${ }^{2}$ and Steven B Roberts ${ }^{1 *}$
}

\begin{abstract}
Background: Ocean acidification as a result of increased anthropogenic $\mathrm{CO}_{2}$ emissions is occurring in marine and estuarine environments worldwide. The coastal ocean experiences additional daily and seasonal fluctuations in $\mathrm{pH}$ that can be lower than projected end-of-century open ocean $\mathrm{pH}$ reductions. In order to assess the impact of ocean acidification on marine invertebrates, Pacific oysters (Crassostrea gigas) were exposed to one of four different $p \mathrm{CO}_{2}$

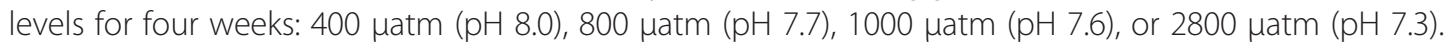

Results: At the end of the four week exposure period, oysters in all four $p \mathrm{CO}_{2}$ environments deposited new shell, but growth rate was not different among the treatments. However, micromechanical properties of the new shell were compromised by elevated $p \mathrm{CO}_{2}$. Elevated $p \mathrm{CO}_{2}$ affected neither whole body fatty acid composition, nor glycogen content, nor mortality rate associated with acute heat shock. Shotgun proteomics revealed that several physiological pathways were significantly affected by ocean acidification, including antioxidant response, carbohydrate metabolism, and transcription and translation. Additionally, the proteomic response to a second stress differed with $p \mathrm{CO}_{2}$, with numerous processes significantly affected by mechanical stimulation at high versus low $\mathrm{pCO}_{2}$ (all proteomics data are available in the ProteomeXchange under the identifier PXD000835).

Conclusions: Oyster physiology is significantly altered by exposure to elevated $p \mathrm{CO}_{2}$, indicating changes in energy resource use. This is especially apparent in the assessment of the effects of $\mathrm{pCO}_{2}$ on the proteomic response to a second stress. The altered stress response illustrates that ocean acidification may impact how oysters respond to other changes in their environment. These data contribute to an integrative view of the effects of ocean acidification on oysters as well as physiological trade-offs during environmental stress.
\end{abstract}

Keywords: Shell deposition, Fatty acid, Proteomics, Ocean acidification, Shell mechanical properties, Pacific oyster

\section{Background}

Current measurements of surface ocean $\mathrm{pH}$ have revealed decreases that are in accordance with modeled predictions of a $\mathrm{pH}$ decline of at least 0.3 units corresponding to atmospheric $p \mathrm{CO}_{2}$ of 650-970 ppm by the year 2100 [1-6]. The coastal ocean, home to productive fisheries and diverse ecosystems, may see even greater changes in $\mathrm{pH}$ due to natural processes (i.e. hydrography, freshwater input, and biological activity) [7-11] and a plethora of anthropogenic effects (i.e. deforestation, agriculture, mining, increasing population sizes [7]). Although some species that live in the coastal ocean show a degree of adaptation to variable $\mathrm{pH}[12,13]$ sessile invertebrates are sensitive to

\footnotetext{
* Correspondence: sr320@uw.edu

'University of Washington, School of Aquatic and Fishery Sciences, Box 355020, Seattle, WA 98195, USA

Full list of author information is available at the end of the article
}

acute low $\mathrm{pH}$ exposures across life stages. In bivalves, low $\mathrm{pH}$ results in significant changes to larval development (e.g. [14]), reduced shell deposition in most species (e.g. $[15,16])$, decreased integrity of the shell $[17,18]$ and weakened attachment of byssal threads [19]. In addition to phenotypic impacts, elevated $p \mathrm{CO}_{2}$ can result in significant shifts in marine invertebrate metabolism and resource utilization (e.g. [20]).

The Pacific oyster, Crassostrea gigas, is a marine invertebrate that has been well studied in terms of its response to ocean acidification. Larvae experience developmental delay and shell malformations in response to low pH [14,21-24]. Adults are also affected negatively by ocean acidification. Fertilization success is reduced at moderately elevated $p \mathrm{CO}_{2}(600 \mu \mathrm{atm})$ [23]. Calcification rates for adult $C$. gigas decrease linearly with increasing $p \mathrm{CO}_{2}$ [15]. Reduced $\mathrm{pH}$ also alters response to other 
environmental variables. The standard metabolic rate of Pacific oysters at low $\mathrm{pH}$ was significantly elevated in response to increasing temperature compared to oysters at ambient $\mathrm{pH}$ [25]. Such studies illustrate that ocean acidification causes profound physiological changes in $C$. gigas that may have long-term consequences on fitness.

To examine the underlying processes associated with the biological impacts of ocean acidification on marine invertebrates, the current study takes an integrative approach in examining the response of adult oysters from alterations in protein abundance to shell deposition rates, shell micromechanical structure, tissue glycogen and fatty acid contents, mortality in response to acute heat shock, and proteomic response to mechanical stress. Oysters were exposed to one of four $p \mathrm{CO}_{2}$ levels (400, $800,1000$, or $2800 \mu \mathrm{atm})$ for one month. The $p \mathrm{CO}_{2}$ values represent approximate current-day surface ocean $p \mathrm{CO}_{2}$ $(400 \mu \mathrm{atm})$ and three elevated values reflecting potential end-of-century scenarios as well as $p \mathrm{CO}_{2}$ variation that is currently experienced in the nearshore environment. At the end of one month the impacts of elevated $p \mathrm{CO}_{2}$ on shell growth, shell micromechanical properties, lipid metabolism, glycogen metabolism, response to acute heat shock, and response to mechanical stress were assessed.

Acute heat shock and mechanical stress represent a test of the mechanistic limits of the stress response and a simulation of ecological stress, respectively. Whereas the oysters may not experience a heat shock in their natural environment that attains the temperature of the one we applied, the stressor serves as an assessment of the mortality response to an intense environmental change. The mechanical stress stimulates a more subtle, yet significant, stress response that is physiologically similar to the oyster's response to other relevant environmental stresses [26,27].

By taking this integrative approach, these data highlight the complex nature of phenotypic impacts of ocean acidification, while at the same time uncovering the less accessible underlying physiological processes. The latter was made possible by the use of shotgun proteomics, applied for the first time in an investigation of the effects of ocean acidification. Shotgun proteomics is a powerful non-biased approach in the investigation of biological responses, which also offers insight into underlying mechanisms that could lead to phenotypic effects. Together these data demonstrate the scope of effects that ocean acidification can have on a marine invertebrate.

\section{Results \& discussion}

Ocean acidification is an on-going and global scale phenomenon that has been shown to negatively impact most taxonomic groups. A large number of studies have characterized these negative impacts across species and life stages (e.g. [28,29]). With the goal of achieving a better understanding of the effects of ocean acidification and responses to additional acute stressors across multiple physiological processes, we employed an integrative approach, combining analyses of shell micromechanical properties, fatty acids, glycogen concentration, and proteomics. Our findings illustrate the value of using complementary approaches to explore interactions and trade-offs among different fundamental processes during environmental stress.

\section{Seawater chemistry analysis}

The $p \mathrm{CO}_{2}$ levels for the four different treatments remained consistent throughout the one month experiment (Table 1). Average pH ( \pm s.d.) for treatments as measured by the DuraFET probe were $8.02 \pm 0.02,7.73 \pm 0.04$, $7.63 \pm 0.10$, and $7.29 \pm 0.10$ for the $400,800,1000$, and $2800 \mu \mathrm{atm}$ treatments, respectively. Spectrophotometric $\mathrm{pH}$ corroborated the DuraFET measurements (spectrophotometric $\mathrm{pH}$ data not shown). The $\mathrm{pCO}_{2}$ in containers with oysters was approximately $40 \mu$ atm higher than the source water $p \mathrm{CO}_{2}$, except for the $2800 \mu \mathrm{atm}$ treatment where it was approximately $75 \mu$ atm lower than the source water. Total alkalinity was $9 \%$ higher in the chambers (data not shown) compared to the source water for 400 $\mu \mathrm{atm}, 10 \%$ higher at $800 \mu \mathrm{atm}, 13 \%$ higher at $1000 \mu \mathrm{atm}$, and $3 \%$ lower at $2800 \mu \mathrm{atm}$. Calcite was undersaturated $\left(\Omega_{\mathrm{c}}<1.0\right)$ only at the highest $p \mathrm{CO}_{2}$ level and aragonite was undersaturated at the two highest $p \mathrm{CO}_{2}$ levels (1000 $\mu$ atm and $2800 \mu \mathrm{atm})$.

\section{Oyster growth}

Relative growth rate (RGR) for shell mass of oysters exposed to increased $p \mathrm{CO}_{2}$, as measured by buoyant weight, was not significantly different among treatments $(\mathrm{p}>0.05)$ (Table 2). Shell mass changed with time across all treatments $(\mathrm{F}=6.1190, \mathrm{p}=0.014)$, indicating shell growth. The lack of significant difference in growth among treatments is somewhat surprising, especially considering that calcite, the main component of adult oyster shells, was undersaturated in the $2800 \mu \mathrm{atm}$ treatment. Over longer exposures to ocean acidification, other bivalve species have demonstrated decreased shell growth as compared to individuals held at ambient $p \mathrm{CO}_{2}$. After six weeks, mussel (Mytilus edulis) shell length growth was negatively impacted by elevated $p \mathrm{CO}_{2}$ of 2400 and $4000 \mu \mathrm{atm}$ [16]. Juvenile oysters, Crassostrea virginica, also had relatively lower shell mass after 45 days at $1665 \mu \mathrm{atm}$ [30] and after a 20 week exposure at $3523 \mu \mathrm{atm}$ [31]. Based on these data we might expect to see differences in shell growth if exposure was continued for a longer period of time. In addition to the duration of exposure, elevated $p \mathrm{CO}_{2}$ may in fact prompt an overcompensation in terms of shell deposition. For instance, hard shell clams, Mercenaria mercenaria, had higher shell mass at moderately elevated $p \mathrm{CO}_{2}$ (about $800 \mu \mathrm{atm}$ ) after 
Table 1 Water chemistry summary data

\begin{tabular}{|c|c|c|c|c|c|c|c|c|c|}
\hline $\begin{array}{l}\text { Treatment } \\
\left(\mathrm{ppm} \mathrm{CO}_{2}\right)\end{array}$ & $\mathrm{pH}$ & Temperature $\left({ }^{\circ} \mathrm{C}\right)$ & Salinity & $A_{T}(\mu \mathrm{mol} / \mathrm{kg})$ & $\begin{array}{l}\text { Source water } \\
\mathrm{pCO}_{2} \text { ( } \mu \text { atm) }\end{array}$ & $\begin{array}{l}\text { Oyster container } \\
\mathrm{pCO}_{2} \text { ( } \mu \text { atm) }\end{array}$ & $\begin{array}{l}\Omega \\
\text { (calcite) }\end{array}$ & $\begin{array}{l}\Omega \\
\text { (aragonite) }\end{array}$ & $\begin{array}{l}\mathrm{CO}_{3}^{2-} \\
(\mu \mathrm{mol} / \mathrm{kg})\end{array}$ \\
\hline 400 & $8.02 \pm 0.02$ & $12.97 \pm 0.41$ & $29.9 \pm 0.2$ & $2085.4 \pm 15.9$ & $427 \pm 33$ & $464 \pm 54$ & $2.7 \pm 0.1$ & $1.7 \pm 0.1$ & $109.0 \pm 5.8$ \\
\hline 800 & $7.73 \pm 0.04$ & $12.92 \pm 0.41$ & $29.9 \pm 0.2$ & $2086.4 \pm 12.1$ & $810 \pm 61$ & $936 \pm 17$ & $1.6 \pm 0.1$ & $1.0 \pm 0.1$ & $65.3 \pm 4.3$ \\
\hline 1000 & $7.63 \pm 0.10$ & $12.82 \pm 0.21$ & $29.9 \pm 0.3$ & $2084.9 \pm 15.3$ & $991 \pm 10$ & $1119 \pm 40$ & $1.3 \pm 0$ & $0.8 \pm 0$ & $54.7 \pm 1.2$ \\
\hline 2800 & $7.29 \pm 0.10$ & $12.87 \pm 0.51$ & $29.9 \pm 0.2$ & $2085.6 \pm 14.9$ & $2848 \pm 603$ & $2776 \pm 603$ & $0.5 \pm 0.1$ & $0.3 \pm 0.1$ & $22.0 \pm 4.5$ \\
\hline
\end{tabular}

Mean and \pm standard deviation are provided for the 29 day experiment. Salinity is an average of nineteen measurements and $A_{T}$ was measured four times. pH and temperature values are from the continuous monitoring by the DuraFET probe. $\mathrm{pH}$, temperature, salinity, and $A_{T}$ were directly measured and all other parameters were calculated using $\mathrm{CO}_{2}$ calc [68].

16 and 21 weeks of exposure, but no significant difference in shell mass between the control treatment and highly elevated $p \mathrm{CO}_{2}$ (about $1500 \mu \mathrm{atm}$ ) was observed [18]. At least some of the variability in the effects of elevated $p \mathrm{CO}_{2}$ on shell growth is likely due to intra- and interspecies differences in population history of exposure to low $\mathrm{pH}$ events.

\section{Micromechanical properties}

Micromechanical properties were tested within the outer $3 \mathrm{~mm}$ of the growing edge (posterior) of left shell valves for oysters in the treatments of 400, 1000, and $2800 \mu \mathrm{atm}$. Both Vickers microhardness and fracture toughness differed significantly among $p \mathrm{CO}_{2}$ treatments (microhardness: Welch ANOVA, $\mathrm{p}=0.014$; fracture toughness: one-way ANOVA, $\mathrm{p}=0.003$ ) (Figure 1). The microhardness of shells grown at $1000 \mu$ atm was significantly lower than that of shells grown at $400 \mu$ atm (Games-Howell: $\mathrm{p}<0.05)$. Shells grown at $2800 \mu \mathrm{atm}$ showed a trend toward lower microhardness as compared to the $400 \mu$ atm control group, but this comparison was not statistically significant (Games-Howell: $\mathrm{p}=0.119$ ). In contrast, fracture toughness was significantly lower in shells grown at 2800 $\mu$ atm as compared to both the 400 and $1000 \mu$ atm treatments, but the 400 and $1000 \mu$ atm treatments did not differ (Tukey HSD: p <0.05). Representative cracks formed by micromechanical testing are shown in Additional file 1 : Figure S1.

Both microhardness and fracture toughness are affected by the arrangement and dimensions of the microstructures that comprise the shell and the extent and distribution of elastic elements within the shell (i.e. the shell organic matrix) [32]. Hence, exposure to elevated $p \mathrm{CO}_{2}$ may lead to dose-dependent differences in the structure

Table 2 Average buoyant weight $\pm 95 \%$ confidence intervals at start and end of experiment

\begin{tabular}{lll}
\hline $\mathbf{p C O}_{2}$ ( $\mu$ atm) & Mass at start (grams) & Mass at 29 days (grams) \\
\hline 400 & $7.1 \pm 0.5$ & $7.8 \pm 0.6$ \\
800 & $7.0 \pm 0.5$ & $7.6 \pm 0.7$ \\
1000 & $7.1 \pm 0.4$ & $7.4 \pm 0.7$ \\
2800 & $7.6 \pm 0.5$ & $8.1 \pm 0.9$ \\
\hline
\end{tabular}

and/or composition of newly formed shell. Such changes could result either from alterations in the physiology of shell deposition or an inability to prevent dissolution and erosion of individual microstructures under varying seawater hydrochemistry. In the current study, changes to micromechanical properties were detected at both $\Omega_{\text {calcite }}$ $\left(\Omega_{\mathrm{c}}\right)=0.5(2800 \mu \mathrm{atm})$ and at $\Omega_{\mathrm{c}}=1.3(1000 \mu \mathrm{atm})$. Alterations in shell growth and structure would be expected at $\Omega_{\mathrm{c}}<1$, however, there is increasing evidence that shell modifications also occur at $\Omega_{c}>1$. Even when seawater is

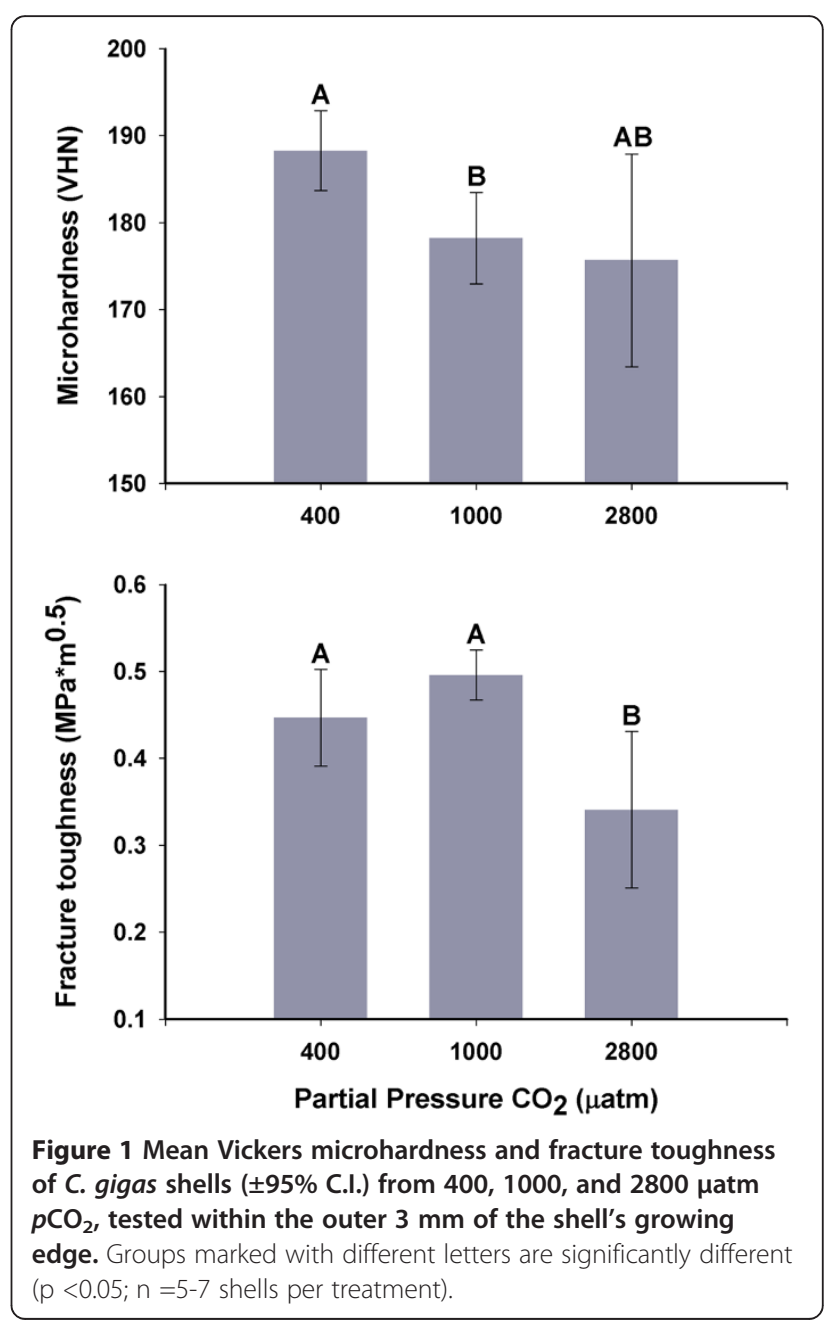


saturated with respect to calcite, bivalves experience both shell dissolution $[18,25]$ and changes to shell microstructure $[18,31,33]$. These results indicate that as $\Omega$ decreases the driving force towards biomineralization is reduced. Source population evolutionary history may also affect sensitivity to changes in $\Omega$. Since calcification is an energetically intensive process [34-36], one explanation for significant effects on $\mathrm{CaCO}_{3}$ structures at $\Omega>1$ is that resources for energy metabolism are being reallocated to other, non-calcification physiological processes in order to maintain homeostasis.

\section{Fatty acids and glycogen}

In order to gain insight into changes in energy metabolism that could be a result of elevated $p \mathrm{CO}_{2}$, we examined fatty acid profiles and glycogen content. Fatty acid profiles did not differ among three treatments $(400,800$, and $2800 \mu \mathrm{atm})(\mathrm{p}>0.05$; Figure 2$)$. The nonmetric multidimensional scaling (NMDS) analysis shows the relative position of each oyster according to its entire fatty acid profile (i.e. oysters that are plotted close together have similar fatty acid profiles). Total fatty acid content (per milligram tissue) did not vary among treatments $(\mathrm{p}>0.05$; data not shown). Twenty-one fatty acid peaks were identified in the 24 samples, which is within the range of 16-35 fatty acids found in other studies of bivalves [37-40]. Some of the more important fatty acids identified were 16:0;
18:0; 18:1n-9; 18:1n-7; 18:2n-6; $\alpha$-linolenic acid (18:3n-3); arachidonic acid (20:4n-6); eicosapentaenoic acid (20:5n-3); two docosapentaenoic acids (22:5n-6 and 22:5n-3); and docosahexaenoic acid (22:6n-3). Raw and normalized fatty acid data are available in Additional file 2: Table S1.

Glycogen content did not differ statistically among treatments (400, 800, and $2800 \mu \mathrm{atm})(\mathrm{p}>0.05$, Figure 3$)$. However, it should be noted that the broad variance in glycogen content within treatments makes it difficult to draw a clear conclusion about the effects of $p \mathrm{CO}_{2}$. For whole body tissue, glycogen measurements ranged from $2466-13808 \mu \mathrm{g} / \mathrm{mg}$ of tissue with a mean $( \pm 95 \%$ confidence interval) glycogen content of $6961 \pm 1406 \mu \mathrm{g} / \mathrm{mg}$ of tissue.

The similar relative proportions of fatty acids and glycogen content in whole body tissue among treatments suggests that extended stress of ocean acidification did not alter fundamental metabolites. Oysters and other bivalves are highly dependent on fatty acids as a main energy source, especially poly-unsaturated fatty acids [38-41]. Changes in physiological state, such as those induced by reproduction or poor nutrient supply, can alter the relative proportions of fatty acids in oyster tissue $[37,40]$. Glycogen stores represent important sources of stored energy that are accumulated during the nonreproductive season and then mobilized for use as glucose during gametogenesis [42]. It is possible that an

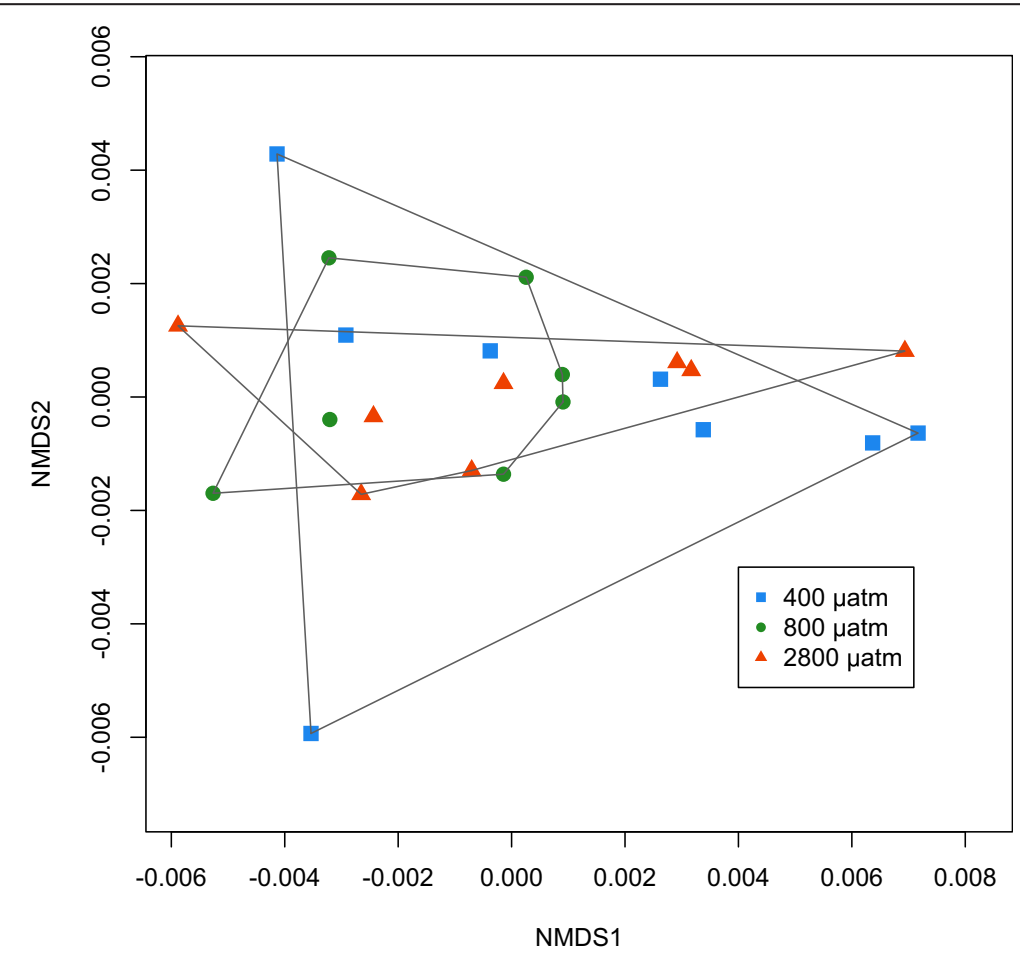

Figure 2 Non-metric multidimensional scaling (NMDS) analysis of fatty acid profiles for oysters from 400,800 and $2800 \mu a t m p \mathrm{CO}_{2}$. There are no differences in relative amounts of fatty acids among the three treatment groups. 


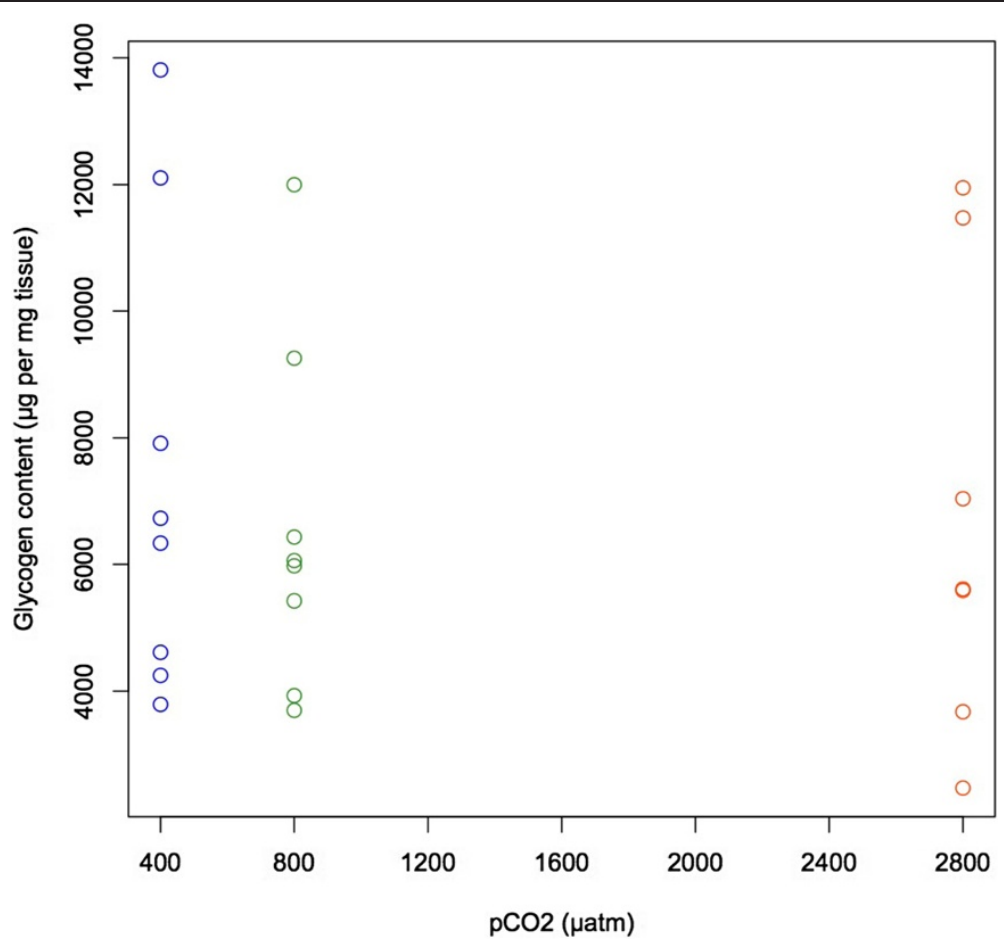

Figure 3 Glycogen content ( $\mu$ g glycogen per mg tissue) for oysters from the $p \mathrm{CO}_{2}$ treatments of 400 (blue), 800 (green), and 2800 (orange) $\mu \mathrm{atm}$. There is no difference in glycogen content among treatment groups.

environmental stress can trigger a change in bivalve physiology and result in changes in lipid or carbohydrate metabolism and/or storage. In the case of ocean acidification, C. gigas is able to maintain homeostasis of both total and relative amounts of both of these energy-providing molecules by restructuring the proteome to metabolize or synthesize lipids and carbohydrates as needed. In contrast to our results, after 11 weeks of exposure to $p \mathrm{CO}_{2}$ of 800 $\mu \mathrm{atm}$, juvenile $C$. virginica had significantly less lipid and glycogen per gram body weight than control oysters [17]. The extended stress of the 11 week exposure in Dickinson et al. [17] may have overwhelmed C. virginica's ability to maintain lipid and carbohydrate homeostasis, suggesting that oyster energy metabolism may fail under consistent ocean acidification stress. There are some instances where ocean acidification did not influence lipid levels in invertebrates. For example, in larval sea urchins, despite the fact that individuals at elevated $p \mathrm{CO}_{2}$ were smaller than control larvae, they maintained the same lipid and protein levels [43].

\section{Heat shock response}

$p \mathrm{CO}_{2}$ did not affect risk of oyster mortality in response to heat shock ( $\mathrm{p}>0.05$ ) (Figure 4) and increased temperature did increase mortality risk $(\mathrm{z}=2.073, \mathrm{p}=0.0382)$. One hundred percent mortality ( $\mathrm{n}=8$ oysters per temperature per treatment) occurred across all three treatments by day
5 post-heat shock at the lethal temperature $\left(44^{\circ} \mathrm{C}\right)$. No mortality occurred by day 6 post-heat shock in the $42^{\circ} \mathrm{C}$ group (data not shown).

Consistent with the hypothesis that elevated $p \mathrm{CO}_{2}$ impacts underlying physiology, we predicted that lower $\mathrm{pH}$ would depress the temperature threshold for mortality after heat exposure. The lack of influence on acute heat shock response across the four $p \mathrm{CO}_{2}$ treatments could be evidence that $p \mathrm{CO}_{2}$ has little effect on the oyster's macro-physiological response. We are not aware of other studies that have investigated ocean acidification and acute heat stress, but there are studies that have explored moderately elevated temperatures and ocean acidification over an extended period. In C. virginica, elevated $p \mathrm{CO}_{2}$ did not impact the oyster's response to elevated temperature [44]. In fact, Ivanina et al. [44] demonstrated that exposure to elevated $p \mathrm{CO}_{2}$ limited high temperature-associated mortality in C. virginica. It appears that extended exposure to elevated $p \mathrm{CO}_{2}$ did not mitigate oyster mortality in response to acute heat shock as it can do with long-term exposure to a moderately elevated temperature.

\section{Proteomics}

After filtering, 700733 peptides were considered for analysis corresponding to 1616 proteins (Additional file 3: Table S2, Additional file 4: Table S3, Table 3). Raw data and ProteinProphet search files are available in the 


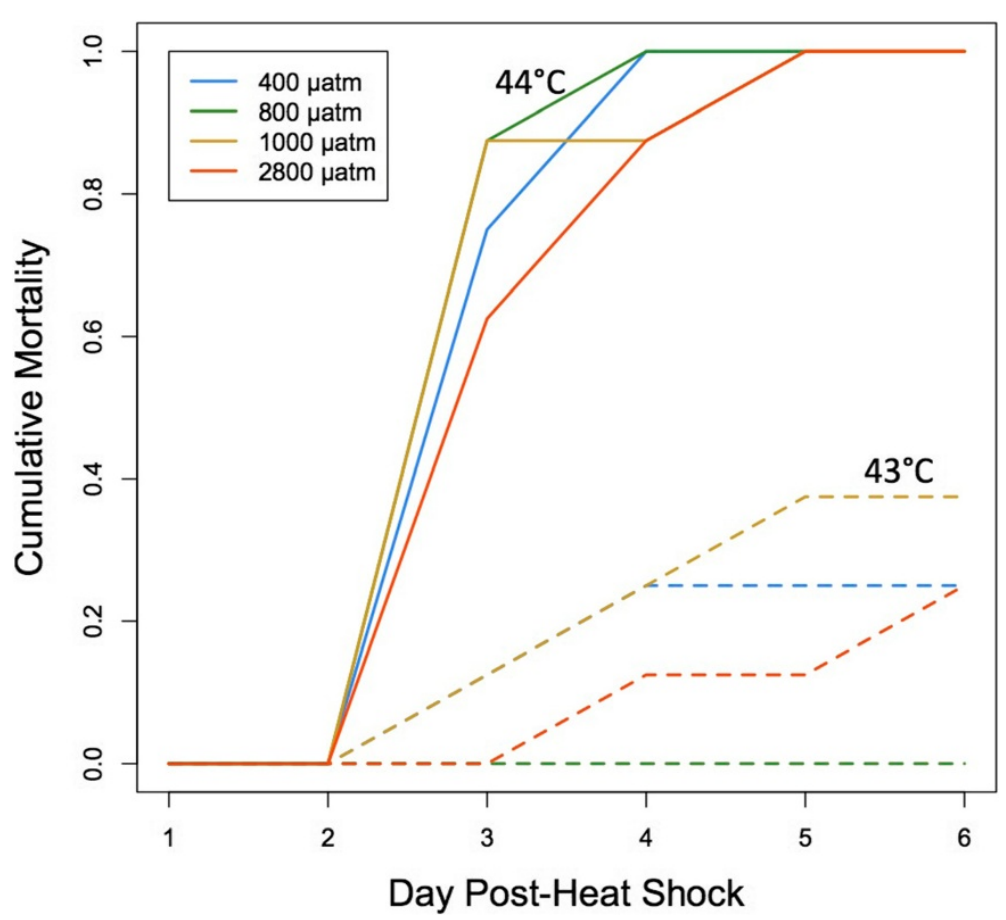

Figure 4 Oyster mortality after 1 hour heat shock at $43^{\circ} \mathrm{C}$ (dashed lines) or $44^{\circ} \mathrm{C}$ (solid lines). Mortality from heat shock did not differ

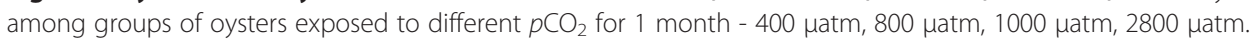

ProteomeXchange with identifier PXD000835. Eightynine percent $(1449)$ of proteins were annotated using the UniProt-KB/SwissProt database and 77\% (1 250) of those were further categorized with Gene Ontology information (Additional file 5: Table S4).
Pairwise comparisons were made based on gill protein expression between 1) oysters held at $400 \mu$ atm versus oysters held at $2800 \mu \mathrm{atm}, 2)$ oysters held at $400 \mu \mathrm{atm}$ versus oysters held at $400 \mu \mathrm{atm}$ subjected to subsequent mechanical stress, and 3) oysters held at $2800 \mu \mathrm{atm}$

Table 3 Total number of proteins identified for each oyster across all three technical replicates with numbers of proteins for each individual technical replicate in parentheses

\begin{tabular}{|c|c|c|}
\hline Oyster ( $\mathrm{pCO}_{2}$ - biological replicate) & Total proteins (Technical replicate \#1, \#2, \#3) & Proteins across all 3 replicates (\% of Total) \\
\hline $400-1$ & $882(869,871,873)$ & $853(96.7 \%)$ \\
\hline $400-2$ & $878(861,863,861)$ & $841(95.8 \%)$ \\
\hline $400-3$ & $836(819,824,819)$ & 802 (95.9\%) \\
\hline $400-4$ & $867(855,856,857)$ & $839(96.8 \%)$ \\
\hline 400-MechS1 & $861(850,850,846)$ & $832(96.6 \%)$ \\
\hline 400-MechS2 & $815(803,806,801)$ & $788(96.7 \%)$ \\
\hline 400-MechS3 & $854(840,848,841)$ & $826(96.7 \%)$ \\
\hline 400-MechS4 & $862(842,850,848)$ & $825(95.9 \%)$ \\
\hline $2800-1$ & $873(854,858,856)$ & 837 (95.9\%) \\
\hline $2800-2$ & $924(910,917,910)$ & $894(96.8 \%)$ \\
\hline $2800-3$ & $901(888,884,893)$ & 871 (96.7\%) \\
\hline $2800-4$ & $874(861,866,865)$ & $849(97.1 \%)$ \\
\hline 2800-MechS1 & $889(877,878,879)$ & $858(96.5 \%)$ \\
\hline 2800-MechS2 & $891(886,876,880)$ & $867(97.3 \%)$ \\
\hline 2800-MechS3 & $867(860,859,856)$ & $844(97.3 \%)$ \\
\hline 2800-MechS4 & $941(923,925,929)$ & $905(96.2 \%)$ \\
\hline
\end{tabular}


versus oysters held at $2800 \mu$ atm subjected to subsequent mechanical stress. The magnitude of the proteomic responses in the three different between-treatment comparisons was similar (245-286 differentially abundant proteins), though many proteins were treatment specific (Figure 5). In addition, for those proteins identified as differentially abundant in more than one comparison, the directional responses of the proteins to each treatment often diverged. For example, proteins in carbohydrate metabolism and nucleotide metabolism were affected differently across treatments (Additional file 6: Figure S2). These contrasting proteomic profile variations were the most dramatic in a comparison between the responses to ocean acidification alone and to mechanical stimulation at high $p \mathrm{CO}_{2}$. All 75 differentially abundant proteins shared between these two responses had opposite relative abundances in response to stress, i.e. if a protein was found at an increased abundance in response to ocean acidification then its abundance was decreased in response to ocean acidification and mechanical stimulation (Additional file 4: Table S3, Additional file 7: Figure S3). Many differentially abundant proteins that were common across stress responses were consistent in having either increased or decreased abundance in response to stress: $96 \%$ of the proteins $(\mathrm{n}=79)$ in the responses to ocean acidification and to mechanical stress at low $p \mathrm{CO}_{2}$ had the same directional change and $76 \%$ of the proteins $(n=25)$ in the responses to mechanical stress at both $p \mathrm{CO}_{2}$.

Forty-eight proteins were differentially abundant in response to all treatments and these represent the general proteomic stress response. These proteins are associated with a wide range of biological processes, including carbohydrate metabolism (malectin and $\alpha$ L-fucosidase), cell adhesion (neurexin-4 and cadherin23), cytoskeleton processes (talin-1, dynein heavy chain 3 , and coactosin), mRNA processing (small nuclear ribonucleoproteins and serine/arginine-rich splicing factor 6), the immune response (allograft inflammatory factor 1), polypeptide and protein degradation (aspartyl aminopeptidase, ubiquitin carboxyl-terminal hydrolase FAF-X, and insulin-degrading enzyme), the stress response (Hsp90 co-chaperone Cdc37, universal stress proteins MSMEG_3950 and A-like), and transcription and translation (nucleolar protein 56, 60S ribosomal proteins L21 and L38, and nucleosome assembly protein 1-like 1).

\section{Proteomic response to elevated $\mathrm{pCO}_{2}$ alone}

Ocean acidification significantly affected the underlying molecular physiology of C. gigas after one month of exposure. The proteomic response of oyster gill tissues under high $p \mathrm{CO}_{2}$ conditions compared to $400 \mu$ atm was characterized by increased abundance of 148 proteins and decreased abundance of 136 proteins (Figure 5A, Additional file 7: Figure S3). Proteins identified as differentially abundant include those involved in carbohydrate metabolism (i.e. $\alpha$-L-fucosidase, probable $\beta$-D-xylosidase 5, succinyl-CoA ligase, and UDP-glucose 4-epimerase), cell growth (i.e. thymidine phosphorylase and tyrosineprotein kinase Yes), transcription and translation (i.e. calcium-regulated heat stable protein 1, prohibitin-2, and translational activator $\mathrm{BCN} 1)$, response to reactive oxygen

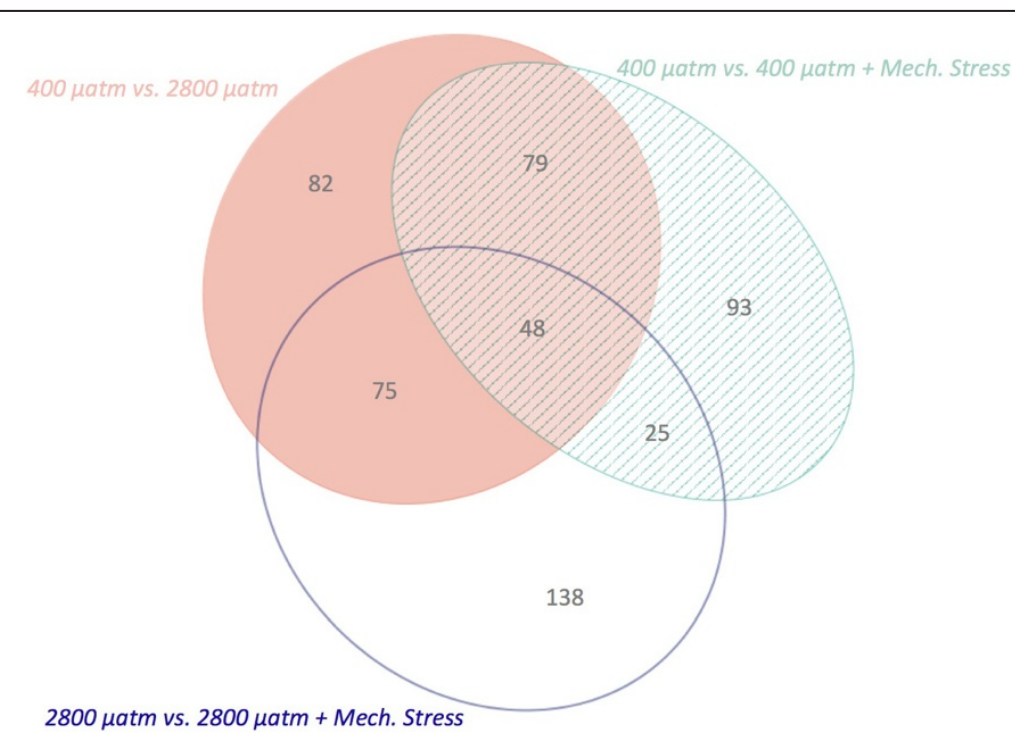

Figure 5 Differentially abundant proteins among treatments. The proteins represented by the solid ellipse were those implicated in the response to ocean acidification alone, those in the open ellipse are different in response to mechanical stress in the $2800 \mu$ atm-exposed oysters, and those in the striped ellipse changed in response to mechanical stress at $400 \mu \mathrm{rtm}$. Numbers represent the number of proteins in each segment of the ellipses. 
species (i.e. glutathione S-transferase $\Omega-1$ ), and signaling (i.e. dual specificity mitogen-activated protein kinase kinase 1, calcium-dependent protein kinase C). Gene enrichment analysis revealed enriched proteins are associated with transcription (i.e. transcription elongation regulator $1,5^{\prime}-3^{\prime}$ exoribonuclease 2), cell junction organization and cell adhesion (i.e. myosin heavy chain 95F, protocadherin Fat 4), and cell proliferation and tissue development (i.e. integrin $\beta$-PS, growth arrest-specific protein 8) (Additional file 8: Table S5). Some of these processes are discussed in more detail below.

Carbohydrate metabolism One clear trend identified in gill protein expression patterns in oysters exposed to elevated $p \mathrm{CO}_{2}$ was the differential abundance of proteins associated with carbohydrate metabolism. Changes in these pathways imply alterations in energetic resource use upon exposure to elevated $p \mathrm{CO}_{2}$. Protein abundance changed for a range of enzymes involved in producing glucose, perhaps revealing a shift in glucose production pathways during ocean acidification stress. Proteins in the galactose metabolism pathway (UDP-glucose 4epimerase, UDP-N-acetylhexosamine pyrophosphorylase, and $\mathrm{N}$-acetylgalactosamine kinase), which can lead to increased glucose production, were detected at higher levels in oysters from the high $p \mathrm{CO}_{2}$ treatment. Those involved in gluconeogenesis (serine-pyruvate aminotransferase) and conversion of other carbohydrates to glucose (glycogen debranching enzyme and pyruvate kinase muscle enzyme) were detected at higher levels in oysters from the low $p \mathrm{CO}_{2}$ treatment. One explanation for these changes is that during exposure to ocean acidification oysters need more glucose production in order to maintain homeostasis. Interestingly, the oysters did not mobilize glycogen stores to meet this demand as glycogen content did not differ among $p \mathrm{CO}_{2}$ treatments in whole body tissue. Glycogen stores may have been maintained because they are typically mobilized as an immediate response to a short-term stress and/or an energetic priority is placed on maintaining glycogen as an investment in fitness. In other taxa (e.g. humans [45] and yeast [46]), the general stress response usually leads to increased carbohydrate metabolism and decreased carbohydrate storage, which is similar to observations from this study. Ocean acidification appears to impact energy resource demands in the oyster, which could be of consequence during periods of immune stress or reproduction, which also require many energetic resources.

Lipid metabolism The abundance of proteins involved in lipid metabolism and transport were significantly affected by exposure to ocean acidification. Proteins implicated in fatty acid metabolism (enoyl-CoA hydratase) and fatty acid transport (fatty acid-binding protein) were detected at higher levels after exposure to elevated $p \mathrm{CO}_{2}$. A protein involved in desaturation and elongation of fatty acids (NADH-cytochrome b5 reductase 1; [47]), likely for incorporation into cellular membranes, was at lower abundance in the ocean acidification-exposed oysters. Highly unsaturated fatty acids are more sensitive to oxidative damage, therefore a lower level of unsaturation may not only protect cellular membranes from reactive oxygen species (ROS) damage but may also protect molecules within the cell (reviewed in [48]). Lipid metabolismassociated genes/proteins were also expressed at higher levels in larval barnacles [49] and adult coral [50] exposed to elevated $p \mathrm{CO}_{2}$. Changes in lipid metabolism, similar to the observed changes in carbohydrate metabolism, represent a shift in how energetic resources are used during extended environmental stress.

Frequently during extended ocean acidification stress bivalves shift from metabolism of mostly carbohydrates and lipids to greater use of protein resources [51,52]. In this study, the observed proteomic changes were not yet reflected at the level of oyster fatty acid profiles (which may also be due to tissue-specific processes), but the results suggest that with extended exposure both carbohydrate and lipid reserves would be altered by exposure to ocean acidification. For example, lipid and glycogen stores were reduced in $C$. virginica after eleven weeks at low $\mathrm{pH}$ [17]. The effects of changes in metabolism may already be seen at the proteomic level in C. gigas with decreased abundance of proteins instrumental to muscle growth (kyphoscoliosis peptidase) and muscle repair (dysferlin) as well as the immune response (lymphocyte cytosolic protein 2 and allograft inflammatory factor 1 ). Maintenance of a robust immune response and of healthy muscle mass are both important for the long-term fitness of oysters and ocean acidification may be affecting these processes via the reallocation of resources.

Oxidative metabolism Oxidative metabolism proteins were also affected by exposure to ocean acidification conditions, imposing further changes on energy supply and perhaps increasing oxidative stress. Increased abundance of proteins cytochrome c oxidase and $\mathrm{NADH}$ dehydrogenase implies that oysters exposed to elevated $p \mathrm{CO}_{2}$ experienced a heightened demand for energy (i.e. increased ATP production in mitochondria). Additionally, the abundance of prohibitin increased after exposure to elevated $p \mathrm{CO}_{2}$. In mammals, greater levels of prohibitin are associated with regulating mitochondrial respiration during stress [53]. Heightened metabolism can occur in response to an ongoing stress [45] and may be an important adaptive strategy to counteract the physiological effects of elevated environmental $p \mathrm{CO}_{2}$ [54]. However, this response can be species specific: increased metabolic rate 
was observed in $M$. mercenaria's response to elevated $p \mathrm{CO}_{2}$ and temperature [55], while C. gigas' metabolic rate was suppressed [25]. Expression of proteins and genes associated with metabolic processes are among the most common changes when invertebrates are exposed to elevated $p \mathrm{CO}_{2}$. Genes and proteins associated with metabolism were detected at lower levels in larval urchins [56], adult corals [50], larval oysters [57,58], and larval tube worms [59]. In the mantle tissue of C. virginica, proteins associated with energy metabolism were expressed at higher levels after exposure to low $\mathrm{pH}$ [60]. Most of these other studies revealed down-regulation of metabolic pathways, while we found a shift between different pathways, perhaps indicating preferred methods of metabolism during stress. These slight differences in results may be due to life stage and tissue type or simply the increased sensitivity of using shotgun proteomics.

Cellular stress Elevated abundance of antioxidant response proteins (two isoforms of glutathione S-transferase $\Omega-1)$ and cytochrome P450 1A5, which produces ROS, provided further evidence of increased oxidative metabolism. The cellular need for an antioxidant response could arise from greater ROS generation during increased metabolism [61] or ocean acidification may directly lead to oxidative stress through elevated cellular $\mathrm{CO}_{2}$ and $\mathrm{H}^{+}[60,62]$. Nucleoside diphosphate kinase homo$\log 5$, a protein that prevents apoptosis, was detected at lower levels at elevated $p \mathrm{CO}_{2}$. Perhaps as a result of increased oxidative stress, the apoptotic response was also elevated. Additionally, autophagy was increased through the relatively greater abundance of CDGSH iron-sulfur domain-containing protein 2 . Evidence of oxidative stress at the protein/gene level $[50,51,60]$ as well as apoptosis $[50,56]$ were also observed to increase in other invertebrates exposed to elevated $p \mathrm{CO}_{2}$. The findings in this and in previous studies support the universal occurrence of increased oxidative stress during invertebrate exposure to ocean acidification.

In the current study, a broad-scale increase in abundance of chaperones and stress response proteins was observed in response to elevated $p \mathrm{CO}_{2}$ (heat shock 70 $\mathrm{kDa}$ protein 4, HSP90 co-chaperone $\mathrm{Cdc} 37$, universal stress protein A-like protein, Hsc70-interacting protein, universal stress protein MSMEG_3950, and stressinduced-phosphoprotein 1), providing further evidence of increased cellular stress and damage during ocean acidification exposure. These results contrast with other studies, which generally report decreased abundance of cell stress proteins and genes in response to ocean acidification $[49,50,56]$, however increased expression of hsp70 was reported in C. gigas [51]. Some of these discrepancies among studies may be due to differences in life stage, tissue type, amount of food available, or equilibrium among transcription, translation, and post-translational modifications. It is clear that elevated $p \mathrm{CO}_{2}$ impacts the cellular stress response, but likely in a manner that addresses the changing physiological needs of the organism.

DNA repair transcription, and translation There were widespread changes in proteins involved in DNA repair, transcription, and translation in oysters exposed to elevated $p \mathrm{CO}_{2}$, illustrating a significant molecular response to the physiological effects of ocean acidification. At the nucleotide level, changes in protein abundance included decreased nucleoside metabolism (purine nucleoside phosphorylase) and differential abundance of proteins associated with nucleotide metabolism (nicotinamide riboside kinase 1 and adenylosuccinate lyase). Concurrently, DNA repair proteins were detected at lower levels in high $p \mathrm{CO}_{2}$-exposed oysters (poly [ADP-ribose] polymerase 3, RuvB-like 2, and X-ray repair cross-complementing protein 5 ) and six cell growth proteins were found to be differentially abundant (three at increased levels: hemicentin-1, thymidine phosphorylase, and tyrosine protein kinase yes). One hypothesis for this observation is that the decrease in DNA repair proteins coupled with changes in nucleotide metabolism may indicate a shift away from repairing DNA damaged by increased oxidative stress.

Abundance of proteins associated with transcription and translation would necessarily change in order to support the myriad other molecular responses to ocean acidification. The importance of these processes is reflected in the enrichment of proteins associated with transcription in the differentially abundant proteins in response to $p \mathrm{CO}_{2}$, mechanical stimulation, and both stressors at once. In ocean acidification-exposed oysters, twenty-two proteins associated with transcription and mRNA processing were differentially abundant. In terms of protein synthesis and degradation, six proteins associated with amino acid metabolism were differentially abundant: two were detected at lower levels at in $2800 \mu \mathrm{atm}$-exposed oysters (amidohydrolase ytcJ and betaine-homocysteine S-methyltransferase 1) and four at elevated levels (aminoacylase-1, dihydrolipoyl dehydrogenase, glutaryl-CoA dehydrogenase, and C-1tetrahydrofolate synthase). Twenty-three proteins involved in protein synthesis and translation were differentially abundant and eleven proteins associated with protein degradation underwent significant changes in abundance, including increased levels of two that prevent protein degradation (cystatin-B, ubiquitin caroxyl-terminal hydrolase FAF-X). In larval sea urchins, genes associated with translation decreased in abundance in response to elevated $p \mathrm{CO}_{2}$ [56], while in larval barnacles and adult C. virginica these proteins increased $[49,60]$. Transcription and translation are the processes that support all other molecular 
and phenotypic changes. The large number of differentially abundant proteins involved in these processes illustrates their integral role in responding to environmental stress and in proteomic plasticity.

\section{The effects of $\mathrm{pCO}_{2}$ on the stress response}

Elevated $p \mathrm{CO}_{2}$ alone may be a stressor for many species, but it may also impair the ability to respond to other physical, chemical, or biological stressors. To investigate the ability of an organism to respond to stressors under ocean acidification conditions, we additionally subjected oysters to mechanical stimulation. Qualitative differences between the proteomic responses to mechanical stimulation at 400 and $2800 \mu \mathrm{atm}$ were reflected in the enrichment analysis, identifying differences between treatment groups at the process level.

Two hundred forty-five proteins were differentially abundant upon mechanical stimulation at $400 \mu \mathrm{atm}$. One hundred seven were elevated under mechanical stress and 138 proteins decreased in abundance (Figure 6B, Additional file 7: Figure S3). The proteins that were differentially abundant included those involved in apoptosis (i.e. programmed cell death protein 5, CDGSH iron-sulfur domain-containing protein 2), carbohydrate metabolism (i.e. $\alpha$-L-fucosidase, lysosomal $\alpha$-mannosidase, phosphoacetylglucosamine mutase), and transcription and translation (i.e. histone deacetylase complex subunit SAP18, eukaryotic translation initiation factor 3 subunit A). Significantly enriched biological processes in the response to mechanical stress included RNA metabolism (i.e. histone deacetylase complex subunit SAP18, U1 small nuclear ribonucleoprotein A), transcription (i.e. nucleosome assembly protein 1-like 1), and gamete generation (i.e. tyrosine-protein kinase Btk29A).

One hundred forty-nine proteins were elevated and 137 proteins were detected at decreased levels when oysters held at $2800 \mu \mathrm{atm}$ were subjected to mechanical stress (Figure 6C, Additional file 7: Figure S3). Differentially abundant proteins included those involved in response to reactive oxygen species (i.e. glutathione S-transferase $\mu 3$ and dual oxidase 2), apoptosis (i.e.
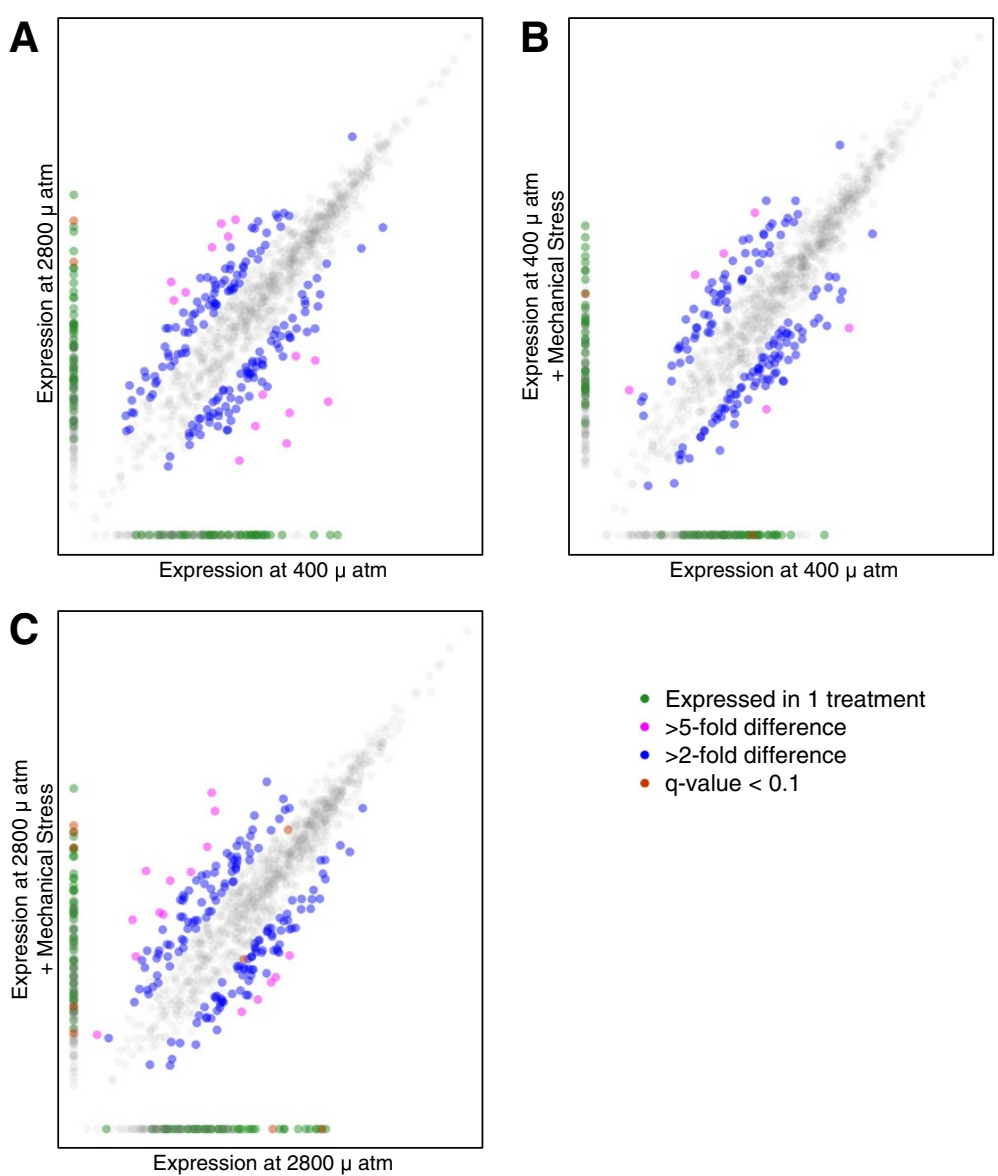

- Expressed in 1 treatment

- >5-fold difference

- $>2$-fold difference

- q-value $<0.1$ to examine the influence of ocean acidification (A), mechanical stress at $400 \mu \mathrm{atm}(\mathrm{B})$, and mechanical stress at $2800 \mu \mathrm{atm}$ (C). Differentially abundant proteins (as defined in the methods) are represented by the bolder, colored dots and non-differentially abundant proteins appear in faint, light gray. 
caspase-7 and engulfment cell motility protein 2), cell adhesion (i.e. protocadherin Fat 4, contactin), and signaling (i.e. E3 ubiquitin-protein ligase $\mathrm{M} \mid \mathrm{B} 2$, prohormone-4). Polysaccharide metabolism and synthesis processes were affected by mechanical stress at elevated $p \mathrm{CO}_{2}$ as evidenced by their enrichment in this treatment, resulting from the differential abundance of proteins including glycogen debranching enzyme, glycogenin-1, UDPglucose 6-dehydrogenase, putative glycogen [starch] synthase, lysosomal $\alpha$-glucosidase, and $\beta$-hexosaminidase subunit $\beta$ (Additional file 4: Table S3). Transcription was also significantly enriched in this stress response (i.e. transcription elongation regulator 1 and basic leucine zipper and W2 domain-containing protein 1).

At the metabolic pathway level, there were different proteomic responses to mechanical stimulation between the two $p \mathrm{CO}_{2}$ treatments. Specifically, in the mechanically stimulated $2800 \mu \mathrm{atm}$-exposed oysters, there were increased levels of proteins that convert stored glycogen into glucose (glycogen debranching enzyme, lysosomal $\alpha$-glucosidase, and glycogenin-1) as well as proteins involved in gluconeogenesis (glucose-6-phosphate isomerase and serine-pyruvate aminotransferase). Rapid mobilization of glycogen stores to make glucose is a common physiological response to stress. Muscle glycogen depleted rapidly in bulls subjected to social and adrenaline stress [63] and liver glycogen similarly decreased in tilapia after confinement stress [64]. In food-stressed rainbow trout an additional handling stress caused a rapid decrease in liver glycogen and increase in plasma glucose [65]. The same exogenous stress in oysters held at low $p \mathrm{CO}_{2}$ prompted a decrease in abundance of proteins associated with carbohydrate metabolism and gluconeogenesis (neutral $\alpha$-glucosidase $\mathrm{AB}$, glucose-5-phosphate isomerase, and $\alpha-\mathrm{N}$-acetylgalactosaminidase) as well as increased abundance of a protein in the glycogen synthesis pathway (putative glycogen [starch] synthase), implying a relatively decreased need for readily available carbohydrate resources. At both $p \mathrm{CO}_{2}$, fewer lipid metabolism proteins were differentially abundant (four proteins at $400 \mu \mathrm{atm}$ and three at $2800 \mu \mathrm{atm})$ compared to carbohydrate metabolism. Mechanical stimulation is a transient stress and carbohydrates represent a more readily available resource compared to lipids for a short-term response. The different changes observed in response to mechanical stimulation illustrate that an additional stress at high $p \mathrm{CO}_{2}$ necessitated greater resource use and a need to access energy reserves. Given the resources needed to sustain a response to an environmental stress, this increase in energetic demand could be detrimental.

In contrast to the proteomic response to mechanical stimulation at $400 \mu \mathrm{atm}$, oysters from the elevated $p \mathrm{CO}_{2}$ treatment had decreased levels of many proteins associated with oxidative metabolism and had a much larger antioxidant response. Four mitochondrial NADH dehydrogenases were detected at lower levels after mechanical stimulation in the high $p \mathrm{CO}_{2}$ oysters, while at low $p \mathrm{CO}_{2}$ three were detected at higher levels and one was decreased. Expression levels of cytochrome b-c1 complex, cytochrome $\mathrm{c}$, and cytochrome c oxidase subunit $5 \mathrm{~B}$ were elevated in the $2800 \mu \mathrm{atm}$ after mechanical stress (and were not affected at low $p \mathrm{CO}_{2}$ ). These abundance changes suggest that at high $p \mathrm{CO}_{2}$ mechanical stress caused a decrease in electron supply from NADH to the electron transport chain (ETC) but an increase in the transfer of electrons to the terminal oxidase, while at low $p \mathrm{CO}_{2}$ more electrons entered the ETC from NADH. In marine invertebrates ROS production occurs during forward electron transport (reviewed in [66]) and a decrease in electron supply may be a physiological compensation against further ROS production. Greater oxidative stress at high versus low $p \mathrm{CO}_{2}$ was also evidenced by the increased abundance of five antioxidant response proteins upon mechanical stimulation at elevated $p \mathrm{CO}_{2}$ (glutathione S-transferase (GST) A, GST 3, GST $\mu$ 3, thioredoxin domain-containing protein 17 , and dual oxidase 2) compared to just one protein at low $p \mathrm{CO}_{2}$ (GST $\Omega$-1). These changes are further evidence that ocean acidification alters the cellular balance between energy resource supply and oxidative stress, especially upon exposure to an additional exogenous stressor.

Ocean acidification appears to significantly impact apoptotic and cellular stress responses of oysters exposed to mechanical stress (Additional file 6: Figure S2). Mechanical stimulation elicited a larger response in apoptosis pathways at $400 \mu \mathrm{atm}$ with differential abundance of five proteins (programmed cell death protein 5 , CDGSH iron-sulfur domain-containing protein 2, histidine triad nucleotide-binding protein 1, EF-hand domaincontaining protein $\mathrm{D} 2$, and programmed cell death protein 6). At $2800 \mu \mathrm{atm}$ only two proteins involved in apoptosis were differentially abundant: caspase- 7 decreased in abundance and engulfment cell motility protein 2 increased in abundance. Five cell stress response proteins increased in abundance upon mechanical stimulation in $400 \mu \mathrm{atm}$-exposed oysters (protein lethal(2)essential for life, hsp90 co-chaperone Cdc37, Hsc70-interacting protein, and universal stress proteins A-like and MSMEG_3950), while four increased in the $2800 \mu \mathrm{atm}$-exposed (Hsp90 co-chaperone $\mathrm{Cdc} 37$, MAP kinase-activated protein kinase 2 , heat shock $70 \mathrm{kDa}$ protein $12 \mathrm{~B}$, and universal stress protein $\mathrm{S} \|$ 1388). These data suggest that mechanical stress is associated with apoptosis, which would be consistent with cell damage. However, apoptosis and the cellular stress response follow slightly different trajectories in response to mechanical stimulation at different $p \mathrm{CO}_{2}$ perhaps reflecting different resource availability in responding to the cellular damage inflicted by the additional stress. Changes to the normal apoptotic and 
stress responses could be detrimental to oysters, highlighting the importance of considering other environmental conditions when examining biological impacts of ocean acidification.

Stress from mechanical stimulation impacted abundance of proteins involved in many of the processes that were influenced by elevated $p \mathrm{CO}_{2}$, further illustrating the potential synergistic impacts of these two stressors on oyster physiology. Together these protein expression patterns indicate the complex nature of how multiple stressors influence physiology and how exposure to additional stressors (i.e. increased temperature or disease exposure) in combination with ocean acidification could have significant implications for survival and potential for adaptation.

\section{Conclusions}

Ocean acidification is frequently portrayed as being detrimental to marine calcifiers, but its effects on invertebrates range well beyond changes to the calcification process. In this study, a wide variety of processes and responses were assessed in the Pacific oyster's response to elevated $p \mathrm{CO}_{2}$ to better understand the physiological trade-offs that occur during this particular stress response. Shell growth was not affected by ocean acidification after one month, but elevated $p \mathrm{CO}_{2}$ did affect the integrity of the deposited shell material. Relative amounts of fatty acids and glycogen content, which are necessary for continued survival and execution of other energy-consuming processes, were also unaltered at elevated $p \mathrm{CO}_{2}$. Mortality in response to acute heat shock remained unaffected as well. The proteomic profile of $C$. gigas gill tissue was significantly altered by ocean acidification, elucidating the molecular physiological costs of elevated environmental $p \mathrm{CO}_{2}$. These changes in proteomic profile suggest that oysters experience shifts in their energy budget as they allocate resources to combat extended exposure to ocean acidification. From a proteomics perspective, ocean acidification also affected C. gigas's response to mechanical stress. Shell integrity and response to a second stress become important in a dynamic environment, and in this way ocean acidification may decrease $C$. gigas fitness under chronic exposure. This research demonstrates the utility in applying proteomics technology to a study of environmental stress response in a wild population, which could lead to developing more targeted tools for studies of environmental toxicology and building models for response to $p \mathrm{CO}_{2}$ stress.

\section{Methods}

\section{Ocean acidification system}

This experiment was conducted in a flow-through system at the Friday Harbor Labs Ocean Acidification Environmental Laboratory, Friday Harbor, Washington, USA where oysters were exposed to $p \mathrm{CO}_{2}$ values of $400 \mu$ atm, 800 $\mu \mathrm{atm}, 1000 \mu \mathrm{atm}$, or $2800 \mu \mathrm{atm}$. The system and control of water chemistry has been previously described in detail $[19,24]$. Briefly, incoming water was filtered $(0.2 \mu \mathrm{m})$ and stripped of $\mathrm{CO}_{2}$. As the water flowed into the different treatment tanks, $\mathrm{CO}_{2}$-free air and $\mathrm{CO}_{2}$ were added back to reach set points that were continuously monitored by a DuraFET III pH probe (Honeywell, Morristown, NJ, USA). From the treatment tanks, water flowed into the eight replicate chambers for each of the four treatment levels at $57.5 \mathrm{~mL} / \mathrm{min}$. For this experiment, set points were calculated for $13^{\circ} \mathrm{C}$ and estimated total alkalinity $\left(\mathrm{A}_{\mathrm{T}}\right)$ of $2100 \mu \mathrm{mol} / \mathrm{kg}$ for $p \mathrm{CO}_{2}$ values of $400 \mu \mathrm{atm}(\mathrm{pH} 8.03)$, $800 \mu \mathrm{atm}(\mathrm{pH} 7.76), 1000 \mu \mathrm{atm}(\mathrm{pH} 7.67)$, and 2800 $\mu$ atm (pH 7.24).

\section{Seawater chemistry analysis}

Spectrophotometric $\mathrm{pH}$ was measured for all treatments 19 out of the 29 days of the experiment as described in SOP 6b [67]. On days 5, 7, 11, 14, 20, 24, and 26 spectrophotometric $\mathrm{pH}$ was used to measure the $\mathrm{pH}$ of the water inside two of the eight experimental chambers per treatment to ensure consistency with set points. Salinity was recorded with a conductivity meter (Hach sensION5, Loveland, CO, USA) and treatment temperature was verified with a Fluke 1523 thermometer (Fluke, Everett, WA, USA) whenever spectrophotometric $\mathrm{pH}$ was measured. Total alkalinity $\left(\mathrm{A}_{\mathrm{T}}\right)$ was measured using an open cell titration as described in SOP 3b [67] for the treatment reservoir water and for two chambers on days $5,11,20$, and 26. If the $\mathrm{A}_{\mathrm{T}}$ titration was not done on the day of collection, the water sample was poisoned with mercuric chloride and stored in a sealed borosilicate glass jar. $\mathrm{CO}_{2}$ calc [68] was used to calculate calcium carbonate saturation state of aragonite and calcite, carbonate ion concentration, and $p \mathrm{CO}_{2}$ with $\mathrm{A}_{\mathrm{T}}$ and $\mathrm{pH}$ as inputs and using the following constants: [69] for $\mathrm{CO}_{2}$ constants; [70] for KHSO4; total scale (mol/kg SW) for $\mathrm{pH}$ scale; and [71] for air-sea flux.

\section{Experimental design}

Adult oysters (average shell length \pm s.d. $=51 \pm 5 \mathrm{~mm}$, average width $=38 \pm 6 \mathrm{~mm}$ ) collected from Oyster Bay, Washington on December 29, 2011 were maintained in $3.5 \mathrm{~L}$ chambers ( $\mathrm{n}=6$ oysters per container) and acclimated for two weeks $\left(\mathrm{T}=13^{\circ} \mathrm{C}, \mathrm{pH}=8\right)$. The oysters originated from the same spawning event in March 2011 from approximately 25 broodstock oysters. Oysters were fed 120,000 cells per $\mathrm{mL}$ per day of Shellfish Diet 1800 (Reed Mariculture, Campbell, CA, USA). Containers were cleaned every other day with freshwater to prevent fouling. At the beginning and end of the experiment, buoyant weight was measured. Relative growth rate of oyster cohorts within each treatment was calculated for buoyant weight based on [72]. For each treatment, the difference in means of natural 
log-transformed mass data was divided by 29 days. Analysis of variance was used to determine the main effects and interactions of time and $p \mathrm{CO}_{2}$ on buoyant weight, using the model:

$$
b w \sim t \times p C O 2
$$

where $b w$ is the measured buoyant weight for an oyster, $t$ is time point (either start or end of the experiment) and $p \mathrm{CO}_{2}$ is the treatment condition. Growth rate analyses were performed in $\mathrm{R}$ [73].

Oysters were held in one of four treatments for 29 days. At the end of the treatment period oysters were either immediately sampled $(n=16)$, subjected to mechanical stress by centrifugation in a standard salad spinner (5min, 100rpm) and sampled $(\mathrm{n}=8)$, or subjected heat shock for one hour and sampled $(n=24)$. Centrifugation has previously been shown to stimulate a stress response in oysters as evidenced by increased circulating noradrenaline and impacts on hemocyte function [26,27]. In this study, mechanical stimulation was used to characterize how elevated $p \mathrm{CO}_{2}$ impacts the physiological response to an additional stressor.

For sampling, a section of the posterior gill lamellae was dissected and immediately flash frozen in liquid nitrogen for protein expression analysis. The intent of the proteomics work was to focus on metabolic responses in the oyster to understand overall shifts in energy allocation. Gill, or ctenidia, tissue is frequently analyzed in oyster molecular response studies as it is metabolically active and is the interface between the oyster and its environment. Only samples held at $400 \mu \mathrm{atm}$ (control) and $2800 \mu \mathrm{atm}$, both mechanically stressed and without additional stress, were considered for protein analysis. Even though 2800 $\mu$ atm may seem like an extreme $p \mathrm{CO}_{2}$, oysters as nearshore animals frequently experience large, short-term fluctuations in $p \mathrm{CO}_{2}$ from both natural and physical processes $[74,75]$ that may impact how they respond to more prolonged low $\mathrm{pH}$ events. Remaining viscera from all oysters were put in a separate tube and flash frozen for fatty acid and glycogen analyses. Both shell valves were gently cleaned of remaining tissue and left to air dry for characterization of shell mechanical properties.

\section{Shell micromechanical properties}

Micromechanical testing was conducted on left shell valves of $C$. gigas that had been exposed to 400, 1000 or $2800 \mu \mathrm{atm}$. All reagents, supplies and equipment for sample preparation were purchased from Allied High Tech Products, Inc. (Rancho Dominguez, CA, USA) unless otherwise stated. Micromechanical testing was conducted within the outermost $3 \mathrm{~mm}$ of the shell posterior, the region of the shell where growth occurs most rapidly. Although we could not definitively differentiate shell grown during the experimental exposure from pre-existing shell, observations of growth during the course of the experiment were consistent with a $3 \mathrm{~mm}$ deposition of new shell.

To prepare samples, shell valves were first cut across their width using a water-cooled diamond tile saw (Skilsaw, \#3540), separating the anterior from the posterior portion of the shell. The posterior segment of valves (approximately $35 \mathrm{~mm}$ in length) was then cleaned using Micro Organic Soap and a cotton ball to remove oil and debris and mounted on a glass microscope slide using mounting wax. Slides with mounted shells were secured to the cutting arm of a low speed diamond saw (TechCut 4 , cooled with proprietary cutting fluid) and the shell segment was cut longitudinally, transecting the most posterior edge. Sectioned shell valves were removed from slides, cleaned again with Micro Organic Soap, dried on a hot plate at $70^{\circ} \mathrm{C}$, and mounted in epoxy resin. Mounted samples were then ground and polished on a manual grinding/polishing machine (M-Prep 5) by passing samples through a grinding series of 180, 320, 600 and 800 grit and then polishing with a $1 \mu \mathrm{m}$ diamond suspension and finally a $0.04 \mu \mathrm{m}$ colloidal silica suspension. Samples were cleaned with Micro Organic soap and checked under a metallurgical microscope after each step of the grinding/polishing process, and were re-polished if necessary until the surface of each sample was completely even and free of scratches. No etching of shells was observed during grinding or polishing.

Vickers microhardness tests were conducted using a microindentation hardness tester (Clark Instrument MHT-1, SUN-TEC, Novi, MI, USA) on polished shells at $0.245 \mathrm{~N}$ load and $5 \mathrm{~s}$ dwelling time. Indents were made within the bulk, foliated layer of the shell, which was easily differentiated from the prismatic and chalky regions of the shell at low magnification. Seven to eight indentations were made per sample and each indent was placed at least $45 \mu \mathrm{m}$ away from other indents and the sample's edges. Vickers hardness numbers (VHN) were calculated as:

$$
V H N=1.854 \times\left(F \div d^{2}\right)
$$

where $\mathrm{F}$ is the applied load and $\mathrm{d}$ is the mean length of the two diagonals produced by indentation. VHN were averaged for each shell sample. Following microhardness testing, each indent was photographed at 80x magnification on a metallurgical microscope (Jenco MET-233, Portland, OR, USA) equipped with a camera (Leica EC3, Buffalo Grove, IL, USA). Photographs were used to quantify the longest crack produced by each indent, which was measured using image analysis software (Leica LAS EZ, Ver. 3.0) as the radius of a circle radiating from the center of the indent enclosing all visible cracks (Additional file 1: Figure S1). Hardness and crack 
radius measurements were used to calculate fracture toughness $\left(\mathrm{K}_{\mathrm{c}}\right)$ for each sample as described elsewhere [76,77]:

$$
K_{C}=0.0154 \times\left(\frac{E}{H}\right)^{1 / 2} \times\left(\frac{P}{C}\right)^{1.5}
$$

where 0.0154 is a calibration constant, $\mathrm{E}$ is an elastic modulus (empirically determined for C. gigas as $73 \mathrm{GPa}$ [32]), $\mathrm{H}$ is hardness in GPa, $\mathrm{P}$ is applied load in $\mathrm{N}$ and $\mathrm{C}$ is crack radius in $\mu \mathrm{m}$.

Statistical analysis for micromechanical properties was conducted using SPSS (Ver. 19, IBM, Armonk, NY, USA). Outliers were calculated in SPSS as values greater than 1.5 times the interquartile range below or above the first or third quartile respectively, and were removed from the dataset (at most two per treatment group). Data were analyzed using one-way analysis of variance followed by post-hoc testing. Normality and equal variance was tested using a Kolmogorov-Smirnov test with Lilliefor's correction and a Levene test, respectively. Fracture toughness data met both assumptions and a Tukey HSD post-hoc test was used. As hardness data was normally distributed but did not meet the equal variance assumption, a Welch ANOVA followed by Games-Howell post-hoc testing was applied.

\section{Fatty acid and glycogen analyses}

Fatty acid and glycogen analyses were carried out on oysters from three $p \mathrm{CO}_{2}$ treatments $(400,800$, and 2800 $\mu \mathrm{atm} ; \mathrm{n}=8$ per treatment for 400 and $2800 \mu \mathrm{atm}, \mathrm{n}=7$ for $800 \mu \mathrm{atm}$ due to poor quality results for one sample). Whole body tissue (minus the dissected gill) was lyophilized overnight and tissues were homogenized with a pestle for use in fatty acid extractions $(2.5 \mathrm{mg}$ per extraction) and glycogen extractions (19.3-84.7 mg). Fatty acid extractions were performed following the protocol described in [78] except two chloroform removals were carried out. Briefly, a chloroform/methanol extraction was used to extract the organic layer from lyophilized tissue (fatty acid extraction). Transmethylation of fatty acids was accomplished by adding toluene and $1 \%$ sulfuric acid in methanol to the dried organic layer and incubating overnight at $50^{\circ} \mathrm{C}$. The aqueous phase, containing fatty acid methyl esters, was then isolated using $\mathrm{KHCO}_{3}$ and hexane/diethyl ether. Fatty acid methyl esters were identified by running the samples on a HP 6958 gas chromatograph with an auto-sampler and flame-ionization detector using an Agilent DB-23 column (30 m, $0.25 \mathrm{~mm}$ diameter, $0.15 \mu \mathrm{m}$ film) (Supelco, Bellefonte, PA, USA). Peaks were identified based on comparison of retention times with known standards. Individual amounts of fatty acids were normalized within each replicate by dividing the peak area by the sum of all fatty acid peak areas for that sample. Normalized fatty acid data were logtransformed and non-metric multidimensional scaling (NMDS) based on a Bray-Curtis dissimilarity matrix was used to compare fatty acid profiles among treatments. NMDS and ANOSIM were performed in $\mathrm{R}$ with the vegan package [73,79].

Glycogen was extracted using trichloroacetic acid (TCA). Three $\mathrm{mL}$ of $15 \%$ TCA was added to each homogenized tissue sample and samples were vortexed and stored at $4^{\circ} \mathrm{C}$ for 1 hour. Samples were then centrifuged at 3,000xg for 10 minutes and $4 \mathrm{~mL}$ of absolute ethanol was added to $500 \mu \mathrm{l}$ of the resulting supernatant. After an overnight incubation at $4^{\circ} \mathrm{C}$, samples were centrifuged 30 minutes at $4,000 \mathrm{xg}$, supernatant was removed, and the resulting glycogen pellet was dissolved in $200 \mu \mathrm{l}$ Nanopure water. Glycogen concentration was determined using Sigma's Glycogen Assay Kit following the manufacturer's protocol (MAK016, Sigma-Aldrich, St. Louis, MO). Each sample was diluted 1:30 in Hydrolysis Buffer and run in triplicate. A few samples that were still too concentrated were run again diluted 1:60. Absorbances were read on a Spectra Max M2 (Molecular Devices, Sunnyvale, CA) at $570 \mathrm{~nm}$ using Softmax Pro v. 5 software (Molecular Devices). The coefficient of variation was $<20 \%$ for all samples. Absorbance measurements were blank corrected and concentrations were corrected for dilution factor and original mass of tissue used for the extraction. Differences among groups were explored using a one-way ANOVA in $\mathrm{R}$ [73] with $p \mathrm{CO}_{2}$ treatment as a fixed factor.

\section{Heat shock}

Oysters from each of the $p \mathrm{CO}_{2}$ treatments of 400, 800, 1000 , and $2800 \mu \mathrm{atm}$ were subjected to acute heat shock to explore the effects of $p \mathrm{CO}_{2}$ exposure on the mechanistic response to this short-term stress. Three temperature shocks were implemented consisting of two sublethal temperatures $\left(42^{\circ}\right.$ and $\left.43^{\circ} \mathrm{C}\right)$ and one lethal temperature $\left(44^{\circ} \mathrm{C}\right)$. The lethal heat shock temperature was previously determined for this group of oysters and is defined as the temperature at which $100 \%$ mortality occurs within one week after a one hour exposure [80]. Eight hundred milliliters of seawater was equilibrated to the correct temperature in a circulating water bath. Since oysters considerably decrease the temperature of the bath, we added a pre-heating step of 10 minutes in one beaker after which the oysters were transferred into another beaker for the full hour. After heat shock, oysters were returned to the flow through system at $\mathrm{pH}=8.03$ and $13^{\circ} \mathrm{C}$. Mortality was the only parameter assessed for the temperature treatment. Differences in mortality across treatments were analyzed using the Cox proportional hazards regression model [81] in $\mathrm{R}$ [73] with $\mathrm{pCO}_{2}$ and temperature as variables. 


\section{Liquid chromatography and tandem mass spectrometry (LC-MS/MS)}

Protein extraction and desalting were performed on gill tissue from four mechanically stressed and four control oysters held in the present day and the highest treatment levels, 400 and $2800 \mu \mathrm{atm}$, respectively ( $\mathrm{n}=16$ oysters total) as described in [82]. Each of the 16 protein samples was injected into the LC-MS/MS three times, with injections occurring in a randomized order. LC-MS/ MS and data acquisition were carried out as previously described [82].

\section{Protein informatics analysis}

Peptide tandem mass spectra were correlated to in silicogenerated tandem mass spectra resulting from the Pacific oyster proteome (database published July 12, 2012 and accessed in August 2012) [83] using SEQUEST [84]. Using PeptideProphet from the trans-proteomic pipeline (TPP), peptides were assigned a relative score for best match to the database $[84,85]$. Only peptides with a PeptideProphet probability score of at least 0.9 were considered for further analysis. Additionally, a protein was considered for analysis only if it had at least 8 spectral counts across all 48 injections ( 1 spectral count $=1$ peptide matched to that protein). Within a biological replicate, a protein was considered to have a non-zero expression value if it had at least 2 unique peptide matches.

NSAF (normalized spectral abundance factor), a metric based on spectral counting [86], was used to quantify protein expression. Total spectral counts $(\mathrm{SpC})$ for each oyster were averaged across the three technical replicates. NSAF was calculated by dividing average $\mathrm{SpC}$ for each protein by the protein length $(\mathrm{L})$ and then dividing $\mathrm{SpC} / \mathrm{L}$ by the sum of all $\mathrm{SpC} / \mathrm{L}$ within a biological replicate [86]. This workflow was executed in SQLShare [87] and workflow and input files are available [88].

Oyster proteins [83] were annotated by comparing sequences to the UniProt-KB/SwissProt database (http:// uniprot.org) using the blastp algorithm [89] with an evalue limit of 1E-10. Based on homology with the SwissProt database, oyster proteins were further annotated with Gene Ontology (GO) and GO parent categories (GO Slim).

Fold change in protein abundance between treatment groups was found by dividing the average NSAF of four biological replicates in one treatment by the average NSAF in the other treatment. In order to statistically test for significant abundance differences, treatments were compared in a pairwise fashion (400 vs. $2800 \mu \mathrm{atm}, 400$ $\mu$ atm vs. $400+$ mechanical stress, and $2800 \mu$ atm vs. $2800+$ mechanical stress) using the qvalue package in $\mathrm{R}$ $[73,90]$ with a q-value cut-off of 0.10 . Use of a q-value instead of a $\mathrm{p}$-value from a $t$-test allows for a multiple comparisons correction using the positive false discovery rate $[91,92]$. In an effort to determine the biological processes that were influenced by altered environmental conditions, proteins were considered differentially abundant if either there was 1) a 2-fold difference in abundance between treatment groups or 2 ) a q-value $<0.10$. All proteins with a q-value $<0.10$ were within the 2 -fold differentially abundant group except for cytochrome b-c1 complex 2, which had an increased expression of 1.5-fold in response to mechanical stress at $2800 \mu \mathrm{atm}$. The two caveats to these differential abundance classifications were that only proteins detected in more than one oyster were considered for fold-based analysis and only proteins expressed by all oysters within a treatment group were considered significant for the q-value cut-off. Proteins detected in only one treatment within a comparison were included in the differentially abundant protein group. These differentially abundant proteins were visualized in iPath2 using Uniprot-KB/SwissProt annotations [93,94] for each treatment comparison. Enrichment analysis was performed on differentially abundant proteins using the Database for Annotation, Visualization, and Integrated Discovery (DAVID) v. 6.7 [95,96] (http://david.abcc.ncifcrf.gov/). The background protein list was made from the entire sequenced gill proteome. Biological processes were considered significantly enriched if $\mathrm{p}$-value $<0.075$. Overlaps in the responses to different stressors were explored using a Venn diagram of the proteins that were differentially abundant between treatments in eulerAPE v. 1.0 (http:// www.eulerdiagrams.org/eulerAPE/).

\section{Availability of supporting data}

All raw data accompanying this manuscript is also available through the data compilation on the biological response to ocean acidification through Ocean Acidification International Coordination Centre (http://doi.pangaea.de/ 10.1594/PANGAEA.837671). The data set supporting the results of this article is available in the ProteomeExchange repository, [PXD000835 http://proteomecentral.proteomexchange.org].

\section{Additional files}

Additional file 1: Figure S1. Representative indents made during micromechanical testing for the (A) $400 \mu \mathrm{atm}$ and (B) $2800 \mu \mathrm{atm} p \mathrm{CO}_{2}$ treatment. The radius of a circle radiating from the center of the indent enclosing all visible cracks was used to calculate fracture toughness, a portion of which is shown for each treatment. Arrow denotes the longest crack found for each indent. Radius length is shown on the image in $\mu \mathrm{m}$.

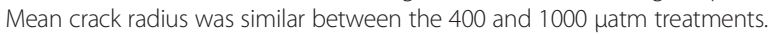

Additional file 2: Table S1. Raw and normalized (proportion) fatty acid data for 8 oysters each from 400 and $2800 \mu a t m p \mathrm{CO}_{2}$ and 7 oysters from $800 \mu \mathrm{atm}$.

Additional file 3: Table S2. ProteinProphet output for each technical replicate. Information for each protein includes percent coverage by sequenced peptides, total number unique peptides, total independent spectra (spectral count), and peptide sequences. 
Additional file 4: Table S3. Protein abundance values (NSAF) for each oyster for the 1616 proteins identified. Also included are average abundance values across treatments (i.e. 2800 avg NSAF is the average abundance across all four high $p \mathrm{CO}_{2}$-exposed oysters); fold change for treatment/control oysters (i.e. Fold Diff OA is [2800 avg NSAF]/[400 avg NSAF]); columns for each of the three treatment comparisons with an asterisk indicating if the protein is $>5$-fold higher or lower levels; SwissProt annotation, e-value, and gene description; proteins responsible for enrichment and the treatment comparisons in which they are enriched; a column indicating in which stress treatment proteins are differentially abundant (q-value $<0.1$ ). In the fold difference columns "up" signifies that the protein was only detected in oysters from the 2800 ratm treatment (versus the $400 \mu$ atm, Fold Diff OA), mechanical stress at $400 \mu$ atm treatment (versus 400 Matm, Fold Diff 400 MechS), or in the mechanical

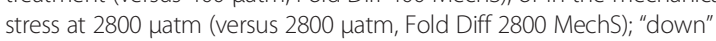
represents proteins that were only detected in the other treatment for each comparison.

Additional file 5: Table S4. C. gigas proteins with associated SwissProt/ UniProt-KB, Gene Ontology (GO), and GO Slim annotations.

Additional file 6: Figure S2. Representation of key metabolic pathways that are significantly affected by ocean acidification (A), mechanical stress at low $p \mathrm{CO}_{2}(\mathrm{~B})$, and mechanical stress at high $p \mathrm{CO}_{2}(\mathrm{C})$. Red lines represent pathways that are more prevalent in the stress treatments and blue lines represent those that are less prevalent. In the key, the different colored lines represent different metabolic pathways that are affected by oyster exposure to ocean acidification and/or mechanical stimulation. Figures are also available on FigShare with input files for iPath2 to allow for interactive exploration of the data [97].

Additional file 7: Figure S3. Heat maps of differentially abundant proteins annotated with protein names. Protein expression values have been log-transformed. The dendrograms on the left of the heat maps represent the clustering of proteins according to expression profile.

Additional file 8: Table S5. Enriched biological processes for proteins $>2$-fold differentially abundant in the stress responses to elevated $p \mathrm{CO}_{2}$ of 2800 matm ("OA"), mechanical stress after a one month exposure to

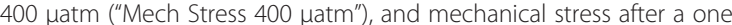
month exposure to $2800 \mu$ tam ("Mech Stress $2800 \mu a t m$ "). Table includes enriched $\mathrm{GO}$ term, number of proteins contributing to that $\mathrm{GO}$ term, $p$-value indicating degree of enrichment, the SwissProt accession numbers for those proteins, the fold enrichment for each GO term, and the false discovery rate (FDR)

\section{Competing interests}

The authors declare that they have no competing interests.

\section{Authors' contributions}

ETS conceived of the experimental design, performed the experiment as well as the lab work for fatty acids, glycogen and proteomics, and wrote the article. WDC and WH performed the mechanical properties testing of the oyster shells, and WDC contributed to mechanical data analysis. GHD provided the resources and experimental design for mechanical properties testing and contributed to writing the manuscript. BLN provided training for the proteomics, assisted in the proteomics analysis, and contributed to writing the manuscript. SBR contributed to the experimental design, proteomics analysis, and manuscript writing. All authors read and approved the final manuscript.

\section{Acknowledgements}

This research was funded in part by the National Oceanographic and Atmospheric Administration Saltonstall-Kennedy Program grant \# NA09NMF4270093 to Dr. Steven Roberts, The College of New Jersey Mentored Undergraduate Summer Experience (MUSE) program, The University of Washington's Proteomics Computer Resource Center (UWPR95794), as well as by contributions from 68 "fuelers" on RocketHub. We would like to thank Taylor Shellfish for the donation of all oysters used in this research, particularly Dr. Joth Davis, Jason Ragan, and Dustin Johnson. Sam Garson and Ronen Elad donated their time to oyster collection and maintenance, respectively. Dr. Carolyn Friedman provided essential advice for many parts of the experimental design as well as edits for the manuscript. Drs. Ken Sebens and Emily Carrington generously provided use of the ocean acidification system at Friday Harbor Labs. Matt George, Dr. Moose O'Donnell, and Michelle Herko were indefatigable in their help with running the experiment and technical troubleshooting. Oyster sampling was aided by Sam White, Dr. Mackenzie Gavery, and Caroline Storer. Thank you pub-a-thon participants and Dr. Lorenz Hauser for comments throughout the manuscript writing process. Dr. Priska von Haller, Jimmy Eng, and Tahmina "Eva" Jahan were indispensable in executing the proteomics portion of the experiment. J. Sean Yeung and Dr. Mike Brett provided training, lab space, and help with analysis for the fatty acids. This work was supported in part by the SQLShare project at the University of Washington eScience Institute.

\section{Author details}

'University of Washington, School of Aquatic and Fishery Sciences, Box 355020, Seattle, WA 98195, USA. ${ }^{2}$ Department of Biology, The College of New Jersey, 2000 Pennington Road, Ewing, NJ 08628, USA. ${ }^{3}$ University of Washington, Genome Sciences, Box 355065, Seattle, WA 98195, USA.

Received: 25 April 2014 Accepted: 29 October 2014

Published: 3 November 2014

\section{References}

1. Caldeira K, Wickett ME: Ocean model predictions of chemistry changes from carbon dioxide emissions to the atmosphere and ocean. J Geophys Res 2005, 110(CO9S04) doi:10.1029/2004JC002671.

2. Feely RA, Alin SR, Newton J, Sabine CL, Warner M, Devol A, Krembs C, Maloy $C$ : The combined effects of ocean acidification, mixing, and respiration on $\mathrm{pH}$ and carbonate saturation in an urbanized estuary. Estuar Coast Shelf Sci 2010, 88(4):442-449. doi:10.1016/j.ecss.2010.05.004.

3. Feely RA, Sabine CL, Byrne RH, Millero FJ, Dickson AG, Wanninkhof R, Murata A, Miller LA, Greeley D: Decadal changes in the aragonite and calcite saturation state of the Pacific Ocean. Glob Biogeochem Cycles 2012, 26(3), GB3001. doi:10.1029/2011GB004157.

4. Friedrich T, Timmermann A, Abe-Ouchi A, Bates NR, Chikamoto MO, Church MJ, Dore JE, Gledhill DK, González-Dávila M, Henemann M, llyina T, Junglclaus JH, McLeod E, Mouchet A, Santana-Casiano JM: Detecting regional anthropogenic trends in ocean acidification against natural variability. Nat Clim Chang 2012, 2:167-171. doi:10.1038/NCLIMATE1372.

5. Gruber N, Hauri C, Lachkar Z, Loher D, Frölicher TL, Plattner G-K: Rapid progression of ocean acidification in the California Current System. Science 2012, 337(6091):220-223. doi:10.1126/science.1216773.

6. Orr JC, Fabry VJ, Aumont O, Bopp L, Doney SC, Feely RA, Gnanadesikan A, Gruber N, Ishida A, Joos F, Key RM, Lindsay K, Maier-Reimer E, Matear R, Monfray P, Mouchet A, Najjar RG, Plattner G-K, Rodgers KB, Sabine CL, Sarmiento JL, Schlitzer R, Slater RD, Totterdell IJ, Wierig M-F, Yamanaka Y, Yool A: Anthropogenic ocean acidification over the twenty-first century and its impact on calcifying organisms. Nature 2005, 437(7059):681-686. doi:10.1038/nature04095.

7. Duarte CM, Hendriks IE, Moore TS, Olsen YS, Steckbauer A, Ramajo L, Carstensen J, Trotter JA, McCulloch M: Is Ocean acidification an open-ocean syndrome? Understanding anthropogenic impacts on seawater $\mathrm{pH}$. Estuar Coasts 2013, 36(2):221-236. doi:10.1007/s12237-013-9594-3.

8. Thomsen J, Gutowska MA, Saphörster J, Heinemann A, Trübenbach K, Fietzke J, Hiebenthal C, Eisenhauer A, Körtzinger A, Wahl M, Melzner F: Calcifying invertebrates succeed in a naturally $\mathrm{CO}_{2}$-rich coastal habitat but are threatened by high levels of future acidification. Biogeosciences 2010, 7:3879-3891.

9. Waldbusser GG, Voigt EP, Bergschneider H, Green MA, Newell RIE: Biocalcification in the Eastern oyster (Crassostrea virginica) in relation to long-term trends in Chesapeake Bay pH. Estuar Coasts 2011, 34(2):221-231.

10. Melzner F, Thomsen J, Koeve W, Oschlies A, Gutowska MA, Bange HW, Hansen HP, Körtzinger A: Future ocean acidification will be amplified by hypoxia in coastal habitats. Mar Biol 2013, 160(8):1875-1888.

11. Baumann H, Wallace RB, Tagliaferri T, Gobler CJ: Large natural $\mathrm{pH}, \mathrm{CO} 2$ and $\mathrm{O} 2$ fluctuations in a temperate tidal salt marsh on diel, seasonal, and interannual time scales. Estuar Coasts 2014, doi:10.1007/s12237-014-9800-y.

12. Kelly MW, Padilla-Gamiño JL, Hofmann GE: Natural variation and the capacity to adapt to ocean acidification in the keystone sea urchin Strongylocentrotus purpuratus. Glob Chang Biol 2013, 19(8):2536-2546. doi:10.1111/gcb.12251. 
13. Pespeni MH, Sanford E, Gaylord B, Hill TM, Hosfelt JD, Jaris HK, LaVigne M, Lenz EA, Russell AD, Young MK, Palumbi SR: Evolutionary change during experimental ocean acidification. Proc Natl Acad Sci U S A 2013, 110(17):6937-6942. doi:10.1073/pnas.1220673110.

14. Barton A, Hales B, Waldbusser GG, Langdon C, Feely RA: The Pacific oyster, Crassostrea gigas, shows negative correlation to naturally elevated carbon dioxide levels: Implications for near-term ocean acidification effects. Limnol Oceanogr 2012, 57(3):698-710. doi:10.4319/lo.2012.57.3.0698.

15. Gazeau F, Quiblier C, Jansen JM, Gattuso J-P, Middelburg JJ, Heip CHR: Impact of elevated $\mathrm{CO}_{2}$ on shellfish calcification. Geophys Res Lett 2007, 34(7), L07603. doi:10.1029/2006GL028554.

16. Melzner F, Stange $P$, Trübenbach $K$, Thomsen J, Casties I, Panknin U, Gorb $\mathrm{SN}$, Gutowska MA: Food supply and seawater $\mathrm{pCO}_{2}$ impact calcification and internal shell dissolution in the blue mussel Mytilus edulis. PLoS One 2011, 6(9):e24223. doi:10.1371/journal.pone.0024223.

17. Dickinson $\mathrm{GH}$, Ivanina $\mathrm{AV}$, Matoo OB, Pörtner HO, Lannig G, Bock C, Beniash $\mathrm{E}$, Sokolova IM: Interactive effects of salinity and elevated $\mathrm{CO}_{2}$ levels on juvenile eastern oysters, Crassostrea virginica. J Exp Biol 2012, 215(1):29-43. doi:10.1242/jeb.061481.

18. Dickinson GH, Matoo OB, Tourek RT, Sokolova IM, Beniash E: Environmental salinity modulates the effects of elevated $\mathrm{CO}_{2}$ levels on juvenile hard-shell clams, Mercenaria mercenaria. J Exp Biol 2013, 216(14):2607-2618. doi:10.1242/jeb.082909.

19. O'Donnell MJ, George MN, Carrington E: Mussel byssus attachment weakened by ocean acidification. Nat Clim Chang 2013, 3(6):587-590. doi:10.1038/nclimate1846

20. Stumpp M, Wren J, Melzner F, Thorndyke MC, Dupont ST: $\mathrm{CO}_{2}$ induced seawater acidification impacts sea urchin larval development I: elevated metabolic rates decrease scope for growth and induce developmental delay. Comp Biochem Physiol A Mol Integr Physiol 2011, 160(3):331-340. doi:10.1016/j.cbpa.2011.06.022.

21. Gazeau F, Gattuso J-P, Greaves M, Elderfield H, Peene J, Heip CHR, Middelburg $\mathrm{J}$ : Effect of carbonate chemistry alteration on the early embryonic development of the Pacific oyster (Crassostrea gigas). PLoS One 2011, 6(8):e23010. doi:10.1371/journal.pone.0023010.

22. Kurihara $\mathrm{H}$, Kato $\mathrm{S}$, Ishimatsu $\mathrm{A}$ : Effects of increased seawater $\mathrm{pCO}_{2}$ on early development of the oyster Crassostrea gigas. Aquat Bio/ 2007, 1(1):91-98. doi:10.3354/ab00009.

23. Parker LM, Ross PM, O'Connor WA: Comparing the effect of elevated $\mathrm{pCO}_{2}$ and temperature on the fertilization and early development of two species of oysters. Mar Biol 2010, 157(11):2435-2452. doi:10.1007/s00227-010-1508-3.

24. Timmins-Schiffman E, O'Donnell MJ, Friedman CS, Roberts SB: Elevated $\mathrm{pCO}_{2}$ causes developmental delay in early larval Pacific oysters, Crassostrea gigas. Mar Biol 2012, 160(8):1973-1982. doi:10.1007/s00227-012-2055-x.

25. Lannig G, Eilers S, Pörtner HO, Sokolova IM, Bock C: Impact of ocean acidification on energy metabolism of oyster, Crassostrea gigas-changes in metabolic pathways and thermal response. Mar drugs 2010 8(8):2318-2339. doi:10.3390/md8082318

26. Lacoste A, Malham SK, Cueff A, Jalabert F, Gélébart F, Poulet SA: Evidence for a form of adrenergic response to stress in the mollusc Crassostrea gigas. J Exp Biol 2001, 204(7):1247-1255

27. Lacoste A, Malham SK, Cueff A, Poulet SA: Stress-induced catecholamine changes in the hemolymph of the oyster Crassostrea gigas. Gen Comp Endocrinol 2001, 122(2):181-188. doi:10.1006/gcen.2001.7629.

28. Kroeker KJ, Kordas RL, Crim R, Hendriks IE, Ramajo L, Singh FS, Duarte CM, Gattuso J-P: Impacts of ocean acidification on marine organisms: quantifying sensitivities and interaction with warming. Glob Chang Biol 2013, 19(6):1884-1896. doi:10.1111/gcb.12179.

29. Kroeker KJ, Kordas RL, Crim RN, Singh GG: Meta-analysis reveals negative yet variable effects of ocean acidification on marine organisms. Ecol Lett 2010, 13(11):1419-1434. doi:10.1111/j.1461-0248.2010.01518.x.

30. Talmage SC, Gobler CJ: Effects of elevated temperature and carbon dioxide on the growth and survival of larvae and juveniles of three species of northwest Atlantic bivalves. PLoS One 2011, 6(10):e26941. doi:10.1371/journal.pone.0026941

31. Beniash E, Ivanina A, Lieb N, Kurochkin I, Sokolova I: Elevated level of carbon dioxide affects metabolism and shell formation in oysters Crassostrea virginica (Gmelin). Mar Ecol Prog Ser 2010, 419:95-108. doi:10.3354/meps08841.

32. Lee SW, Kim GH, Choi CS: Characteristic crystal orientation of folia in oyster shell, crassostrea gigas. Mater Sci Eng C 2008, 28(2):258-263. doi:10.1016/j.msec.2007.01.001.
33. Welladsen HM, Southgate PC, Heimann K: The effects of exposure to near-future levels of ocean acidification on shell characteristics of Pinctada fucata (Bivalvia: Pteriidae). Molluscan Res 2010, 30(3):125-130.

34. Paine RT: Energy flow in a natural population of the herbivorous gastropod Tegula funebralis. Limnol Oceanogr 1971, 16(1):86-98.

35. Palmer AR: Calcification in marine molluscs: how costly is it? Proc Natl Acad Sci U S A 1992, 89(4):1379-1382.

36. Rosenberg GD, Hughes WW: A metabolic model for the determination of shell composition in the bivalve mollusc, Mytilus edulis. Lethaia 1991, 24(1):83-96.

37. Both A, Parrish CC, Penney RW, Thompson RJ: Lipid composition of Mytilus edulis reared on organic waste from a Gadus morhua aquaculture facility. Aquat Living Resour 2011, 301:295-301.

38. Milke LM, Bricelj VM, Parrish CC: Growth of postlarval sea scallops, Placopecten magellanicus, on microalgal diets, with emphasis on the nutritional role of lipids and fatty acids. Aquaculture 2004, 234(1-4):293-317. doi:10.1016/j.aquaculture.2003.11.006

39. Pettersen AK, Turchini GM, Jahangard S, Ingram BA, Sherman CDH: Effects of different dietary microalgae on survival, growth, settlement and fatty acid composition of blue mussel (Mytilus galloprovincialis) larvae. Aquaculture 2010, 309(1-4):115-124. doi:10.1016/j.aquaculture.2010.09.024.

40. Soudant $P$, Van Ryckeghem K, Marty Y, Moal J, Samain JF, Sorgeloos P: Comparison of the lipid class and fatty acid composition between a reproductive cycle in nature and a standard hatchery conditioning of the Pacific Oyster Crassostrea gigas. Comp Biochem Physiol B Biochem Mol Biol 1999, 123(2):209-222. doi:10.1016/S0305-0491(99)00063-2.

41. Trider DJ, Castell JD: Effect of dietary lipids on growth, tissue composition and metabolism of the oyster (Crassostrea virginica). J Nutr 1980, 110(7):1303-1309.

42. Berthelin C, Kellner K, Mathieu M: Storage metabolism in the Pacific oyster (Crassostrea gigas) in relation to summer mortalities and reproductive cycle (West Coast of France). Comp Biochem Physiol Part B 2000, 125:359-369. doi:10.1016/S0305-0491(99)00187-X

43. Matson PG, Yu PC, Sewell MA, Hofmann GE: Development under elevated $\mathrm{pCO}_{2}$ conditions does not affect lipid utilization and protein content in early life-history stages of the purple sea urchin, Strongylocentrotus purpuratus. Biol Bull 2012, 223(3):312-327.

44. Ivanina AV, Dickinson GH, Matoo OB, Bagwe R, Dickinson A, Beniash E, Sokolova IM: Interactive effects of elevated temperature and $\mathrm{CO}_{2}$ levels on energy metabolism and biomineralization of marine bivalves Crassostrea virginica and Mercenaria mercenaria. Comp Biochem Physiol A Mol Integr Physiol 2013, 166(1):101-111. doi:10.1016/j.cbpa.2013.05.016.

45. Mizock BA: Alterations in Carbohydrate metabolism during stress: a review of the literature. Am J Med 1995, 98:75-84.

46. Parrou $J$, Teste M, François J: Effects of various types of stress on the metabolism of reserve carbohydrates in Saccharomyces cerevisiae: genetic evidence for a stress-induced recycling of glycogen and trehalose. Microbiology 1997, 143:1891-1900.

47. Holloway PW, Wakil SJ: Requirement for reduced diphosphoryidine nucleotide-cytochrome b5 reductase in stearyl coenzyme A desaturation. J Biol Chem 1970, 245:1862-1865.

48. Pamplona R, Barja G, Portero-Otín M: Membrane fatty acid unsaturation, protection against oxidative stress, and maximum life span. Ann N Y Acad Sci 2002, 959:475-490

49. Wong KKW, Lane AC, Leung PTY, Thiyagarajan V: Response of larval barnacle proteome to $\mathrm{CO}(2)$-driven seawater acidification. Comp Biochem Physiol Part D Genomics Proteomics 2011, 6(3):310-321. doi:10.1016/j.cbd.2011.07.001.

50. Kaniewska P, Campbell PR, Kline DI, Rodriguez-Lanetty M, Miller DJ, Dove S, Hoegh-Guldberg O: Major cellular and physiological impacts of ocean acidification on a reef building coral. PLoS One 2012, 7(4):e34659. doi:10.1371/journal.pone.0034659.

51. Clark MS, Thorne MAS, Amaral A, Vieira F, Batista FM, Reis J, Power DM: Identification of molecular and physiological responses to chronic environmental challenge in an invasive species: the Pacific oyster, Crassostrea gigas. Ecol Evol 2013, 3(10):3283-3297. doi:10.1002/ece3.719.

52. Michaelidis B, Ouzounis C, Paleras A, Pörtner HO: Effects of long-term moderate hypercapnia on acid - base balance and growth rate in marine mussels Mytilus galloprovincialis. Mar Ecol Prog Ser 2005, 293:109-118.

53. Coates PJ, Nenutil R, McGregor A, Picksley SM, Crouch DH, Hall PA, Wrigth EG: Mammalian prohibitin proteins respond to mitochondrial stress and decrease during cellular senescence. Exp Cell Res 2001, 265:262-273. 
54. Melzner F, Gutowska MA, Langenbuch M, Dupont S, Lucassen M, Thorndyke $\mathrm{MC}$, Bleich $\mathrm{M}$, Pörtner $\mathrm{H}-\mathrm{O}$ : Physiological basis for high $\mathrm{CO}_{2}$ tolerance in marine ectothermic animals: pre-adaptation through lifestyle and ontogeny? Biogeosciences 2009, 6(10):2313-2331. doi:10.5194/bg-6-2313-2009.

55. Matoo OB, Ivanina AV, Ullstad C, Beniash E, Sokolova IM: Interactive effects of elevated temperature and $\mathrm{CO}_{2}$ levels on metabolism and oxidative stress in two common marine bivalves (Crassostrea virginica and Mercenaria mercenaria). Comp Biochem Physiol A Mol Integr Physiol 2013, 164(4):545-553. doi:10.1016/j.cbpa.2012.12.025

56. Todgham AE, Hofmann GE: Transcriptomic response of sea urchin larvae Strongylocentrotus purpuratus to $\mathrm{CO}_{2}$-driven seawater acidification. J Exp Biol 2009, 212(16):2579-2594. doi:10.1242/jeb.032540.

57. Dineshram R, Wong KKW, Xiao S, Yu Z, Qian PY, Thiyagarajan V: Analysis of Pacific oyster larval proteome and its response to high- $\mathrm{CO}_{2}$. Mar Pollut Bull 2012, 64(10):2160-2167. doi:10.1016/j.marpolbul.2012.07.043.

58. Dineshram R, Thiyagarajan V, Lane A, Ziniu Y, Xiao S, Leung PTY: Elevated $\mathrm{CO}_{2}$ alters larval proteome and its phosphorylation status in the commercial oyster. Crassostrea Hongkongensis Mar Biol 2013, 160(8):2189-2205. doi:10.1007/s00227-013-2176-X

59. Mukherjee J, Wong KKW, Chandramouli KH, Qian P-Y, Leung PTY, Wu RSS, Thiyagarajan $\mathrm{V}$ : Proteomic response of marine invertebrate larvae to ocean acidification and hypoxia during metamorphosis and calcification. J Exp Biol 2013, 216(Pt 24):4580-4589. doi:10.1242/jeb.094516.

60. Tomanek L, Zuzow MJ, Ivanina AV, Beniash E, Sokolova IM: Proteomic response to elevated $\mathrm{PCO}_{2}$ level in eastern oysters, Crassostrea virginica: evidence for oxidative stress. J Exp Biol 2011, 214(11):1836-1844. doi:10.1242/jeb.055475.

61. Mohanty P, Hamouda W, Garg R, Aljada A, Ghanim H, Dandona P: Glucose challenge stimulates reactive oxygen species (ROS) generation by leucocytes. J Clin Endocrinol Metab 2000, 85(8):2970-2973.

62. Dean JB: Hypercapnia causes cellular oxidation and nitrosation in addition to acidosis : implications for $\mathrm{CO} 2$ chemoreceptor function and dysfunction. J Appl Physiol 2010, 108:1786-1795. doi:10.1152/japplphysiol.01337.2009.

63. Lacourt A, Tarrant PV: Glycogen depletion patterns in myofibres of cattle during stress. Meat Sci 1985, 15:85-100.

64. Vijayan MM, Pereira C, Grau EG, Iwama GK: Metabolic responses associated with confinement stress in tilapia: The role of cortisol. Comp Biochem Physiol 1997, 116C(1):89-95.

65. Vijayan MM, Moon TW: Acute Handling Stress Alters Hepatic Glycogen Metabolism in Food-Deprived Rainbow Trout (Oncorhynchus mykiss). Can J Fish Aquat Sci 1992, 49:2260-2266

66. Abele D, Philipp E, Gonzalez PM, Puntarulo S: Marine invertebrate mitochondria and oxidative stress. Front Biosci 2007, 12:933-946.

67. Dickson AG, Sabine CL, Christian JR: Guide to best practices for ocean $\mathrm{CO}_{2}$ measurements, PICES Special Publication 3; 2007.

68. Robbins LL, Hansen ME, Kleypas JA, Meylan SC: $\mathrm{CO}_{2}$ calc - A User-Friends Seawater Carbon Calculator for Windows, Mac OS X, and iOS (iPhone), U.S. Geoglogical Survey Open-File Report 2010-1280; 2010.

69. Lueker TJ, Dickson AG, Keeling CD: Ocean $\mathrm{pCO}_{2}$ calculated from dissolved inorganic carbon, alkalinity, and equations for $\mathrm{K}_{1}$ and $\mathrm{K}_{2}$ - validation based on laboratory measurements of $\mathrm{CO}_{2}$ in gas and seawater at equilibrium. Mar Chem 2000, 70:105-119.

70. Dickson A: Thermodynamics of the discussion of boric acid in synthetic seawater from 273.15 to 318.15 K. Deep Sea Res Part A, Oceanogr Res Pap 1990, 37:755-766.

71. Wannikhof R: Relationship between wind speed and gas exchange over the ocean. J Geophys Res 1992, 97:7373-7382.

72. Hoffmann WA, Poorter $\mathrm{H}$ : Avoiding bias in calculations of relative growth rate. Ann Bot 2002, 90(1):37-42. doi:10.1093/aob/mcf140.

73. R Core Team: $R$ : A Language And Environment For Statistical Computing. $R$ Foundation for Statistical Computing. Vienna, Austria: 2013. URL http://www R-project.org/.

74. Hauri C, Gruber N, Plattner G-K, Alin S, Feely RA, Hales B, Wheeler PA: Ocean acidification in the California current system. Oceanography 2009, 22:60-71.

75. Fassbender AJ, Sabine CL, Feely RA, Langdon C, Mordy CW: Inorganic carbon dynamics during northern California coastal upwelling. Cont Shelf Res 2011, 31:1180-1192.

76. Anstis GR, Chantikul P, Lawn BR, Marshall DB: A critical evaluation of indentation techniques for measuring fracture toughness: I, direct crack measurements. J Am Ceram Soc 1981, 46(9):533-538.
77. Baldassarri M, Margolis HC, Beniash E: Compositional determinants of mechanical properties of enamel. J Dent Res 2008, 87(7):645-649. doi:10.1177/154405910808700711

78. Galloway AWE, Britton-Simmons KH, Duggins DO, Gabrielson PW, Brett MT: Fatty acid signatures differentiate marine macrophytes at ordinal and family ranks. J Phycol 2012, 48(4):956-965. doi:10.1111/j.1529-8817.2012.01173.x

79. Oksanen J, Guillaume Blanchet F, Kindt R, Legendre P, Minchin PR, O'Hara RB, Simpson GL, Solymos P, Stevens MHH, Wagner H: Vegan: Community Ecology Package, R package version 2.0-8; 2013. http://CRAN.R-project.org/ package=vegan

80. Clegg JS, Uhlinger KR, Jackson SA: Induced thermotolerance and the heat shock protein - 70 family in the Pacific oyster Crassostrea gigas. Mol Mar Biol Biotechnol 2009, 7(1998):21-30.

81. Therneau TM, Grabsch PM: Modeling Survival Data: Extending the Cox Model. New York: Springer; 2000. ISBN 0-387-98784

82. Timmins-Schiffman E, Nunn BL, Goodlett DR, Roberts SB: Shotgun proteomics as a viable approach for biological discovery in the Pacific oyster. Conserv Physiol 2013, 1(1):cot009-cot009. doi:10.1093/conphys/ cot009.

83. Fang X, Li L, Luo R, Xu F, Wang X, Zhu Y, Yang L, Huang Z: Genomic data from the Pacific oyster (Crassostrea gigas). Gigascience 2012, http://dx.doi.org/10.5524/100030.

84. Eng JK, Mccormack AL, Yates JR: An Approach to correlate tandem mass spectral data of peptides with amino acid sequences in a protein database. J Am Soc Mass Spectrom 1994, 5:976-989.

85. Eng JK, Fischer B, Grossmann J, Maccoss MJ: A fast SEQUEST cross correlation algorithm. J Proteome Res 2008, 7(10):4598-4602. doi:10.1021/ pr800420s.

86. Florens L, Carozza MJ, Swanson SK, Fournier M, Coleman MK, Workman JL, Washburn MP: Analyzing chromatin remodeling complexes using shotgun proteomics and normalized spectral abundance factors. Methods 2006, 40(4):303-311. doi:10.1016/j.ymeth.2006.07.028.

87. Howe B, Cole G, Souroush E, Koutris P, Key A, Khoussainova N, Battle L: Database-As-A-Service For Long-Tail Science. In Proceedings of the 23rd international conference on Scientific and statistical database management (SSDBM'11). Edited by Cushing HB, French J, Bowers S. Heidelberg: Springer; 2011:480-489

88. Timmins-Schiffman E, Roberts SB: SQLShare workflow for proteomics analysis. FigShare 2014, figshare. http://dx.doi.org/10.6084/m9. figshare.894323.

89. Altschul SF, Madden TL, Schäffer AA, Zhang J, Zhang Z, Miller W, Lipman DJ: Gapped BLAST and PSI-BLAST: a new generation of protein database search programs. Nucleic Acids Res 1997, 25(17):3389-3402.

90. Dabney A, Storey JD and with assistance from Warnes GR: Qvalue: Q-Value Estimation For False Discovery Rate Control, R Package Version 1.34.0. 2002.

91. Storey JD: A direct approach to false discovery rates. J R Stat Soc Ser B Stat Methodol 2002, 64(3):479-498. doi:10.1111/1467-9868.00346.

92. Storey JD, Tibshirani R: Statistical significance for genomewide studies. Proc Natl Acad Sci U S A 2003, 100(16):9440-9445. doi:10.1073/ pnas.1530509100.

93. Letunic I, Yamada T, Kanehisa M, Bork P: iPath: interactive exploration of biochemical pathways and networks. Trends Biochem Sci 2008, 33(3):101-103. doi:10.1016/j.tibs.2008.01.001.

94. Yamada T, Letunic I, Okuda S, Kanehisa M, Bork P: iPath2.0: interactive pathway explorer. Nucleic Acids Res 2011, 39(Web Server issue):W412-W415. doi:10.1093/nar/gkr313.

95. Huang DW, Sherman BT, Lempicki RA: Systematic and integrative analysis of large gene lists using DAVID bioinformatics resources. Nat Protoc 2009, 4(1):44-57. doi:10.1038/nprot.2008.211.

96. Huang DW, Sherman BT, Lempicki RA: Bioinformatics enrichment tools: paths toward the comprehensive functional analysis of large gene lists. Nucleic Acids Res 2009, 37(1):1-13. doi:10.1093/nar/gkn923.

97. Timmins-Schiffman E, Roberts SB: iPath2 supplemental information. FigShare 2014, http://dx.doi.org/10.6084/m9.figshare.899908.

doi:10.1186/1471-2164-15-951

Cite this article as: Timmins-Schiffman et al: Shotgun proteomics reveals physiological response to ocean acidification in Crassostrea gigas. BMC Genomics 2014 15:951. 